\title{
Independent Technical Review of Management of Stormwater and Wastewater at the Separations Process Research Unit (SPRU) Disposition Project, New York
}

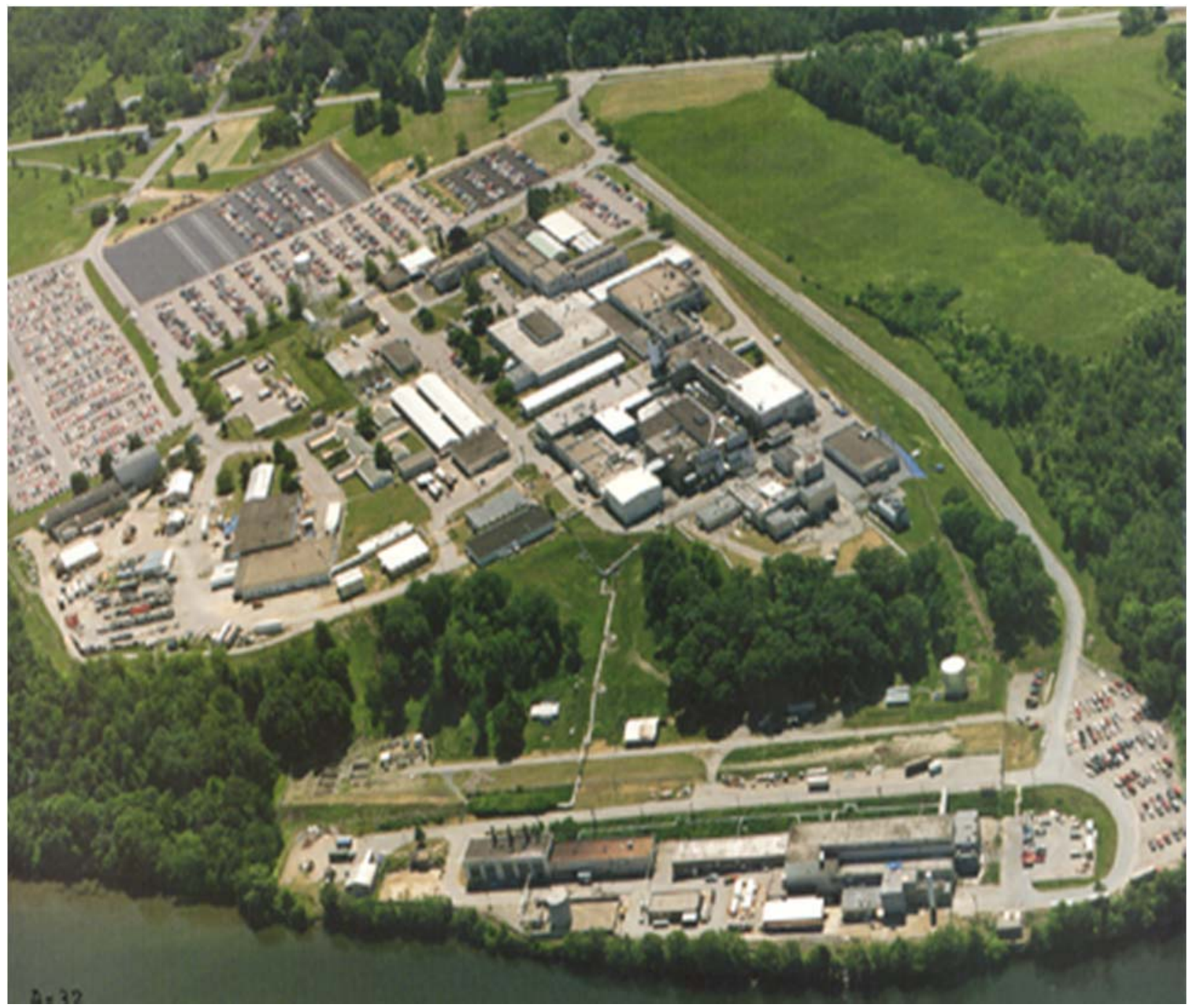

Prepared for: The U.S. Department of Energy (DOE) Environmental Management (EM) Program, Office of Technology Innovation and Development (EM30), Washington, DC

Prepared by: The DOE EM Center for Sustainable Groundwater and Soil Solutions, Savannah River National Laboratory, Aiken SC

June 2011 

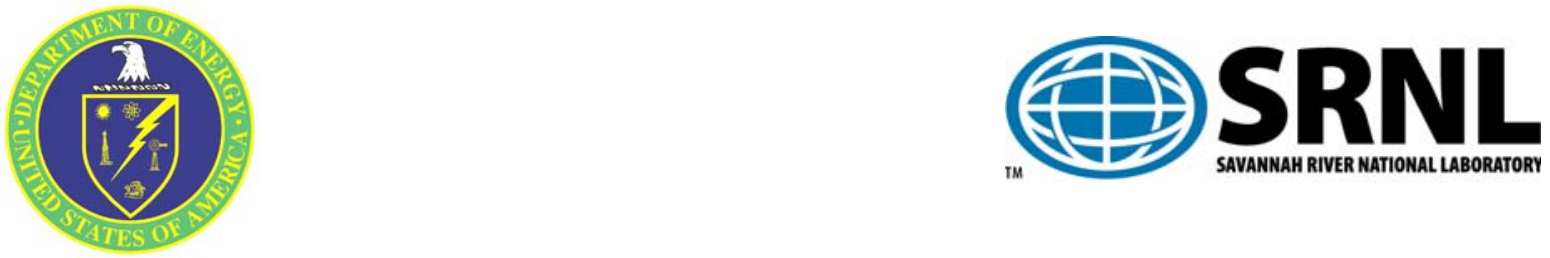

Cover Photo: Aerial view of the Knolls Atomic Power Laboratory and the Separations Process Research Unit (center right). The Mohawk River, shown at the bottom of the photo, is located to the northeast of the facility.

\section{DISCLAIMER}

This work was prepared under an agreement with and funded by the U.S. Government. While the authors have taken care in the preparation of this report, neither the U. S. Government or its employees, nor any of its contractors, subcontractors or their employees, makes any express or implied: 1. warranty or assumes any legal liability for the accuracy, completeness, or for the use or results of such use of any information, product, or process disclosed; or 2. representation that such use or results of such use would not infringe privately owned rights; or 3. endorsement or recommendation of any specifically identified commercial product, process, or service. Any views and opinions of authors expressed in this work do not necessarily state or reflect those of the United States Government, or its contractors, or subcontractors.

Printed in the United States of America

Prepared For

U.S. Department of Energy

Office of Technology Innovation and Development 


\title{
Independent Technical Assessment of Management of Stormwater and Wastewater at the Separations Process Research Unit Disposition Project (SPRU), New York
}

\author{
Authors: \\ Richard J. Abitz \\ Dennis G. Jackson \\ Carol A. Eddy-Dilek
}

Savannah River National Laboratory

Prepared for

Department of Energy (DOE)

Environmental Management (EM)

Office of Technology Innovation and Development

Washington, D.C.

June 2011

Technical content and coordination for this effort was provided by the Savannah River National Laboratory in conjunction with Contract No. DE-AC09-08SR22470 with the U.S. Department of Energy. 
SRNL-STI-2011-00334

\{blank page\}

4 of 43 


\section{Table of Contents}

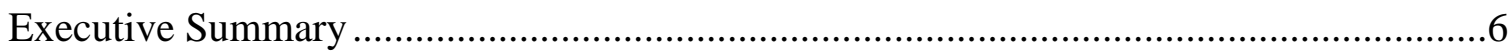

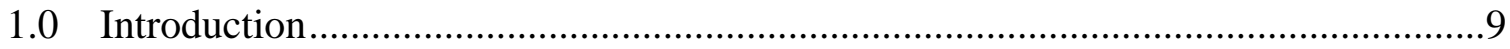

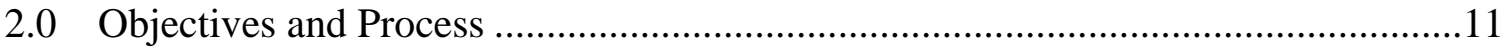

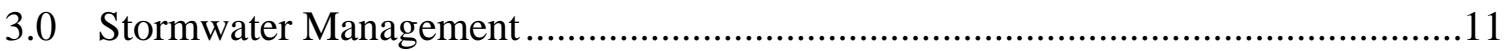

3.1 Configuration of Stormwater Management Prior to D\&D .................................... 16

3.2 Configuration Based on the Stormwater Pollution Prevention Plan...................... 16

3.3 Current Configuration for Stormwater Management.......................................... 17

3.4 Contractor Proposed Stormwater Management Strategy..................................... 19

3.5 Recommendations to Improve the Stormwater Management Strategy .................. 20

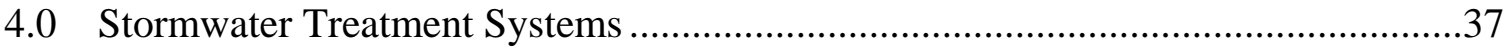

4.1 History of the Stormwater Treatment System ................................................... 37

4.2 Costs Associated with Stormwater Treatment, Shipping and Disposal................. 37

4.3 Observations and Recommendations for Wastewater Treatment ......................... 39

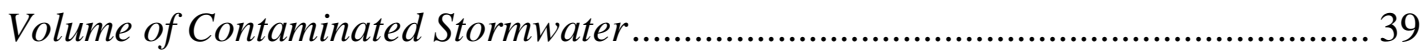

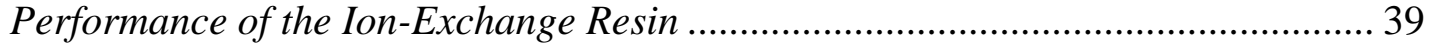

Discharge of Treated Water to the Abandoned Rail Bed .......................................... 40

Cost Comparison for Existing versus New Treatment System .................................. 40

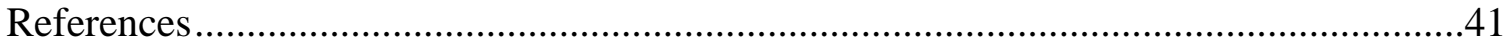




\section{Executive Summary}

Currently, the DOE and contractor management team at the Separations Processing Research Unit (SPRU) Disposition Project (DP) is facing significant issues that are related to collection and treatment of stormwater at the SPRU site. These issues have arisen primarily as a result of the reconfiguration of the SPRU footprint for demolition and decommissioning (D\&D), discontinued use of the storm sewers at the adjacent Knolls Atomic Power Laboratory (KAPL), and contamination events that occurred in the fall of 2010.

Prior to the initiation of D\&D activities at the SPRU-DP, up to 100,000 gallons of wastewater were processed each year using the water treatment system in the basement of Building H2. The treated water was analyzed to demonstrate compliance with the KAPL stormwater discharge permit, and then was released to the KAPL storm sewers.

Mobilization and work activities associated with the decontamination and demolition (D\&D) of Buildings G2 and H2 at SPRU have substantially increased the amount of wastewater that is produced during precipitation events. In preparation for D\&D of Buildings G2 and H2, the stormwater catch basins surrounding the buildings were capped and a French drain system was installed to channel the stormwater to the hillside slope west of the buildings. Some of the French drains were lined with semi-permeable geotextile, which allowed a portion of the stormwater to percolate into the subsurface and collect in waste sumps. Additionally, heavy equipment brought to the site for building demolition damaged the asphalt pads around the buildings so that the integrity of a previously impervious surface was compromised. The increased infiltration interacts with residual VOCs in the subsurface between the facilities. Clean surface water from the surrounding areas now flows into the Building $\mathrm{H} 2$ foundation sump as wastewater, rather than away from the contaminated areas.

Two contamination release events in the fall of 2010 directly impacted the volume of wastewater requiring treatment. After a process tank was ruptured and contamination entered the air pathway, D\&D activities were shut down by the Department of Energy (DOE) Office of Environmental Management (EM), and the partially demolished buildings were left open to the environment for an extended period of time as DOE EM performed a Type $\mathrm{B}$ accident investigation and modified the contract to reflect corrective measures. These collective events resulted in a significant increase in the volume of wastewater that is produced from stormwater as it falls on the contaminated debris and surrounding areas. Additionally, failure of the Hillside sump pumps resulted in a stormwater pollution discharge elimination system (SPDES) permit violation, and a Consent Order was executed by the New York State Department of Environmental Conservation (NYSDEC).

After D\&D operations were shut down and the SPDES violation, KAPL denied permission to DOE to discharge treated wastewater to their storm sewers, and the wastewater was stored in tankers and shipped offsite for disposal. Over a seven month period (November 2010 through May 2011), the contractor shipped over 365,000 gallons 
of wastewater. Recognizing abnormal storm events occurred, this volume extrapolated to one year would equate to approximately 625,000 gallons of wastewater, which is greater than six times the volume of wastewater processed prior to the initiation of D\&D activities at the SPRU-DU.

The existing water treatment system at SPRU was moved out of the basement of Building $\mathrm{H} 2$, and reassembled to the north of Building $\mathrm{H} 2$ during the D\&D preparation activities. The capacity of the treatment system is five to eight gallons per minute (gpm), and the treated water from this system was discharged to the KAPL storm sewer until October of 2010, similar to the process rate and discharge protocol when it was in the basement of Building H2. The system was shut down when D\&D operations were suspended and it was restarted in the spring of 2011, after a disposal contract was established for the treated water. Presently, a small fraction of the wastewater is treated and sent to the DuPont facility in New Jersey, and untreated wastewater is shipped to the PermaFix NW facility in Richland, Washington.

The site contractor is currently proposing to purchase and install a new water treatment system, with a minimum processing rate of $20 \mathrm{gpm}$ that will allow most of the wastewater collected at the site to be treated and shipped to the DuPont facility in New Jersey for disposal.

After a review of historic, present and proposed activities for management and treatment of stormwater and wastewater at the SPRU facility, the team makes the following overarching recommendations:

- DOE should direct the contractor to enforce rigorous stormwater management practices that are focused on reducing the amount of wastewater generated from stormwater events at the site. Many of these practices will be simple to implement and will result in a significant reduction in the amount of wastewater that needs to be collected, treated and shipped offsite.

- DOE should perform a thorough cost analysis of stormwater and wastewater generation and associated treatment and disposal costs to determine the path that will lead to the best project value for DOE. The team believes that if better stormwater management practices are implemented at the site, the existing treatment system, with modification for treatment of volatile organic contaminants, may be adequate to meet the needs of the project.

Specific recommendations regarding stormwater management include:

- Install temporary siding and roof structures on Building G2 to minimize the volume of stormwater entering the facility.

- Slope all areas around Building H2 and the Tank Vault away from the structure to minimize the generation of wastewater from precipitation that enters the H2 footer sump, which drains to the Hillside sump. 
- Place impermeable geotextile under the French drains to eliminate percolation of stormwater into the $\mathrm{H} 2$ footer sump and KAPL storm sewer.

- Establish impervious surfaces for all areas that are not part of the French drain system to minimize the infiltration of precipitation. The "swamp mats" are effective tools to create localized impervious surfaces and may be cost effective, relative to asphalt.

- Incorporate inspections into the stormwater management program that evaluate excess wastewater generation from precipitation events.

- Onsite collection and storage of stormwater should be considered to minimize loading to French drains and provide beneficial reuse of collected water for dust control or other applicable tasks.

- $\quad$ Determine the feasibility of obtaining DOE SPRU-DP SPDES permits.

Significant recommendations regarding wastewater operations include:

- Improve the estimate on the volume of wastewater that will be generated by D\&D activities, and account for better stormwater management practices to minimize this volume.

- Estimate the cost to modify the existing treatment system to process wastewater for disposal at the DuPont NJ facility or discharge to the abandoned rail bed.

- Given that lower wastewater volumes are possible, re-evaluate the requirement that a new treatment system must demonstrate a minimum process rate of $20 \mathrm{gpm}$.

- Compare the cost of modifying the existing system and purchasing and constructing a new system (with similar gpm rates for both systems) to determine the best value for DOE. 


\subsection{Introduction}

The U.S. Department of Energy (DOE) is currently evaluating procedures that are used to manage stormwater and wastewater at the Separations Process Research Unit (SPRU) Disposition Project (DP) on the Knolls Atomic Power Laboratory (KAPL) site in Niskayuna, New York. DOE’s SPRU facility consists of two large buildings and associated facilities that are located in the northwest corner of the KAPL site, which is operated and managed by the Office of Naval Reactors. The SPRU facility served as a pilot plant to research the chemical process for plutonium extraction and was placed into a safe shutdown configuration by DOE in 1953.

In December 2007, DOE issued a task order to URS to complete the decontamination and demolition (D\&D) of the SPRU facilities (Buildings G2 and H2/tank farm), and these activities fall under the SPRU-DP. Building G2 was transferred to the D\&D contractor in 2008 and Building H2 was turned over in 2009. The contractor prepared the buildings for D\&D in 2009 and 2010 by performing energy isolations (cold and dark status), asbestos removal, and improvements to access points for construction equipment. In September 2010, the demolition of the first floor of Building H2 was initiated. During demolition activities, a process tank released radioactive contamination to the air during a cutting operation, and all work activities were shut down. After work activities were stopped for a DOE Type B accident investigation, a 6-inch rainfall from a tropical storm flooded parts of G2 and H2, creating a large volume of contaminated water. In an event unrelated to the tropical storm, a pump electrical failure caused a sump to overflow, and approximately 630 gallons of water was discharged to a drainage channel that empties into the Mohawk River, violating the KAPL SPDES permit and resulting in a Consent Order with the New York State Department of Environmental Conservation (NYSDEC). A summary of the timeline for these and other D\&D events is provided in Table 1.

Currently, the SPRU management team is facing significant issues that are related to collection and treatment of stormwater at the site. These issues have arisen primarily as a result of the reconfiguration of the SPRU footprint for D\&D, discontinued use of the KAPL storm sewers, and contamination events that occurred in the fall of 2010. 
Table 1: Timeline of events for D\&D Activities at the SPRU Facility.

\begin{tabular}{|c|c|}
\hline December 2007 & $\begin{array}{l}\text { DOE issued a task order to URS to complete the decontamination and } \\
\text { demolition (D\&D) of the SPRU facilities. }\end{array}$ \\
\hline 2008 & $\begin{array}{l}\text { URS mobilized, developed and implemented safety management } \\
\text { programs, and took responsibility of Building G2. }\end{array}$ \\
\hline 2009 & $\begin{array}{l}\text { URS assumes responsibility of Building H2; commenced asbestos } \\
\text { abatement, utility facility isolation, and other activities to support entry } \\
\text { into the below grade portions of the building. }\end{array}$ \\
\hline 2010 & $\begin{array}{l}\text { URS continues asbestos abatement, characterization surveys, and utility } \\
\text { isolation. }\end{array}$ \\
\hline September 2010 & URS begins demolition of the first floor of Building $\mathrm{H} 2$. \\
\hline September 29, 2010 & $\begin{array}{l}\text { Three process system vessels in Building H2 were removed during } \\
\text { demolition activities and one vessel was size reduced contrary to work } \\
\text { plans, which resulted in an air release and a contamination event. DOE } \\
\text { initiated a Type B accident investigation. }\end{array}$ \\
\hline September 30, 2010 & $\begin{array}{l}\text { Tropical storm moves into the Albany NY area and } 2.68 \text { inches of rain } \\
\text { falls. }\end{array}$ \\
\hline October 01, 2010 & $\begin{array}{l}\text { Tropical storm stalls in Albany, NY area and } 3.04 \text { inches of rain falls. } \\
\text { Contaminated water generated from precipitation leaching the debris } \\
\text { piles on } \mathrm{H} 2 \text { pad collects in the H2 basement and spills onto ground } \\
\text { outside of the H2 pad. }\end{array}$ \\
\hline October 25, 2010 & $\begin{array}{l}\text { Approximately } 630 \text { gallons of stormwater are released from an overflow } \\
\text { of a holding tank due to an electrical malfunction that failed to terminate } \\
\text { the pumping from the Hillside sump pump system. The contaminated } \\
\text { stormwater enters the KAPL stormwater discharge system and reaches } \\
\text { the Mohawk River as an unpermitted SPDES discharge. }\end{array}$ \\
\hline November 2010 & $\begin{array}{l}\text { KAPL terminates agreement with SPRU for discharge of treated water } \\
\text { to the KAPL storm sewer system. SPRU stormwater treatment system } \\
\text { is shut down. URS begins shipments of untreated wastewater to } \\
\text { PermaFix NW in Richland, WA for treatment and disposal. }\end{array}$ \\
\hline November 03, 2010 & $\begin{array}{l}\text { State of New York Department of Environmental Conservation issues a } \\
\text { Notice of Violation for the unpermitted stormwater discharge on } \\
\text { October } 25,2010 .\end{array}$ \\
\hline November 23, 2010 & DOE issues its report on the Type B accident investigation. \\
\hline December 28, 2010 & $\begin{array}{l}\text { DOE signs Order on Consent with State of New York Department of } \\
\text { Environmental Conservation for an Environmental Benefit Project as } \\
\text { compensation for the unpermitted release of contaminated stormwater } \\
\text { on October 25, } 2010 \text {. }\end{array}$ \\
\hline March 2011 & $\begin{array}{l}\text { DOE and URS enter into a modified contract to restart D\&D work. } \\
\text { Treatment system restarted and treated water sent to DuPont facility in } \\
\text { NJ for disposal. }\end{array}$ \\
\hline May 25,2011 & d off-site reaches 365,000 gallons \\
\hline
\end{tabular}




\subsection{Objectives and Process}

DOE's EM-50 requested technical assistance from EM32 to provide an independent technical panel to review technical issues associated with the management of stormwater and wastewater at the SPRU site (Appendix A). EM 32 selected the Center for Sustainable Groundwater and Soil Solutions at the Savannah River National Laboratory to perform the independent review. Specifically, the team was asked to:

1. Identify critical issues associated with the management and handling of surface/snow melt/run-off water at the SPRU site,

2. Identity critical unresolved technical uncertainties associated with the management of surface/snow melt/run-off water at the SPRU site,

3. Evaluate the current and proposed approach for onsite treatment of contaminated surface water at the SPRU site with an emphasis on unit treatment costs and treatment efficacy.

Members of the technical assistance team visited the SPRU site on May 23, 24 and 25, 2011. The technical team performed the following step-wise process:

o Reviewed background materials provided by DOE,

o Members of the team walked down the components of the surface water management system with a DOE representative,

o Provided a telephone briefing on their initial recommendations on May 26,

o Provided this report consisting of a written set of comments and recommendations.

The technical review team would like to express their appreciation to the DOE personnel at the SPRU facility for their support.

\subsection{Stormwater Management}

During their site visit, the team was able to walk down most of the site to observe the present stormwater and treatment systems. Figure 1 identifies the stormwater system prior to D\&D activities and Figure 2 depicts conditions during $D \& D$ of the above-grade portions of Buildings G2 and H2. The team defined key components of the stormwater system in terms of potential inputs, flow vectors, treatment vectors, and final disposition options (Table 2). Potential inputs into the surfacewater/stormwater system that were identified include precipitation, dust control, runoff from pavement and roofs, the Hillside sump, and basement sumps in building G2 and H2. Flow vectors (KAPL Storm Sewers, French Drain System, Hillside Slope, Tank Cluster A and B) and treatment vectors (existing onsite ion-exchange system, proposed onsite ion-exchange system, and proposed onsite treatment system for volatile organic compounds) bridge the input streams to the waste disposition options. Final disposition options include the two KAPL outfalls (SPDES 002 and SPDES 004), percolation at the rail bed, and offsite treatment at either the DuPont or PermaFix facilities. 
Table 2: Components for stormwater management activities at SPRU

\begin{tabular}{|l|l|l|}
\hline \multicolumn{1}{|c|}{ Water Sources } & \multicolumn{1}{|c|}{ Flow \& Treatment Vectors } & \multicolumn{1}{|c|}{ Final Disposition } \\
\hline Precipitation & KAPL Storm Sewers & SPDES 002 \\
Misting for Dust Control & French Drain System & SPDES 004 \\
Pavement/Roofs & Hillside Slope & Percolation at Rail Bed \\
Hillside Sump & Tank Cluster A & DuPont NJ Facility \\
H2 Basement & Tank Cluster B & PermaFix NW Facility \\
G2 Basement & Present Ion Exchange System & \\
Excavations & New Ion Exchange System & \\
& New VOC Treatment System & \\
\hline
\end{tabular}

Some of the components in Table 2 are not identified on Figures 1 and 2. The Hillside sump is down slope and proximal to the H2 emergency tunnel (Figure 1), and it collects water from the foundation of Building $\mathrm{H} 2$ via the footer sump in the NW corner of the structure (about 26 feet below grade). Tank Cluster A receives water from the Hillside sump and Tank Cluster B receives water from the basement of H2. Figure 3 shows a current picture of the Hillside sump, the tank discharge lines, and the tank clusters on the top of the slope. Tank clusters are positioned north of Building H2 (where the SPRU DU letters appear on Figure 1). The present ion-exchange system is located adjacent to Tank Cluster A. A new ion exchange and VOC treatment system is proposed for future operations, and the suggested location for the proposed system is the lower level of the site; below the slope north of Building $\mathrm{H} 2$ and just off the top of the map on Figure 1. The location suggested for percolating treated water in the abandoned rail bed is also on the lower level of the site, and it will be to the east of the proposed new treatment system.

Based on the components in Table 2, the team developed four scenarios (Figures 4, 5, 6, and 7) that show the conceptual aspects of the historic, present and proposed future stormwater conditions at the site. Active components for a given scenario are shown with solid colors and black text, and non-active components are shown with transparent colors and grey text. Colors for the active components were chosen to qualitatively represent radiological hazard associated with the source or the receptor. Green generally indicates non-hazardous sources (e.g. rainwater, snowmelt, SPDES discharges). Yellow, orange, and red are used to indicate contamination from a radiological perspective with the least contaminated water sources in yellow, followed by orange and then red for the most contaminated source areas. The development of these scenarios is based on the background information provided to the team as well as observations made during the site visit. 


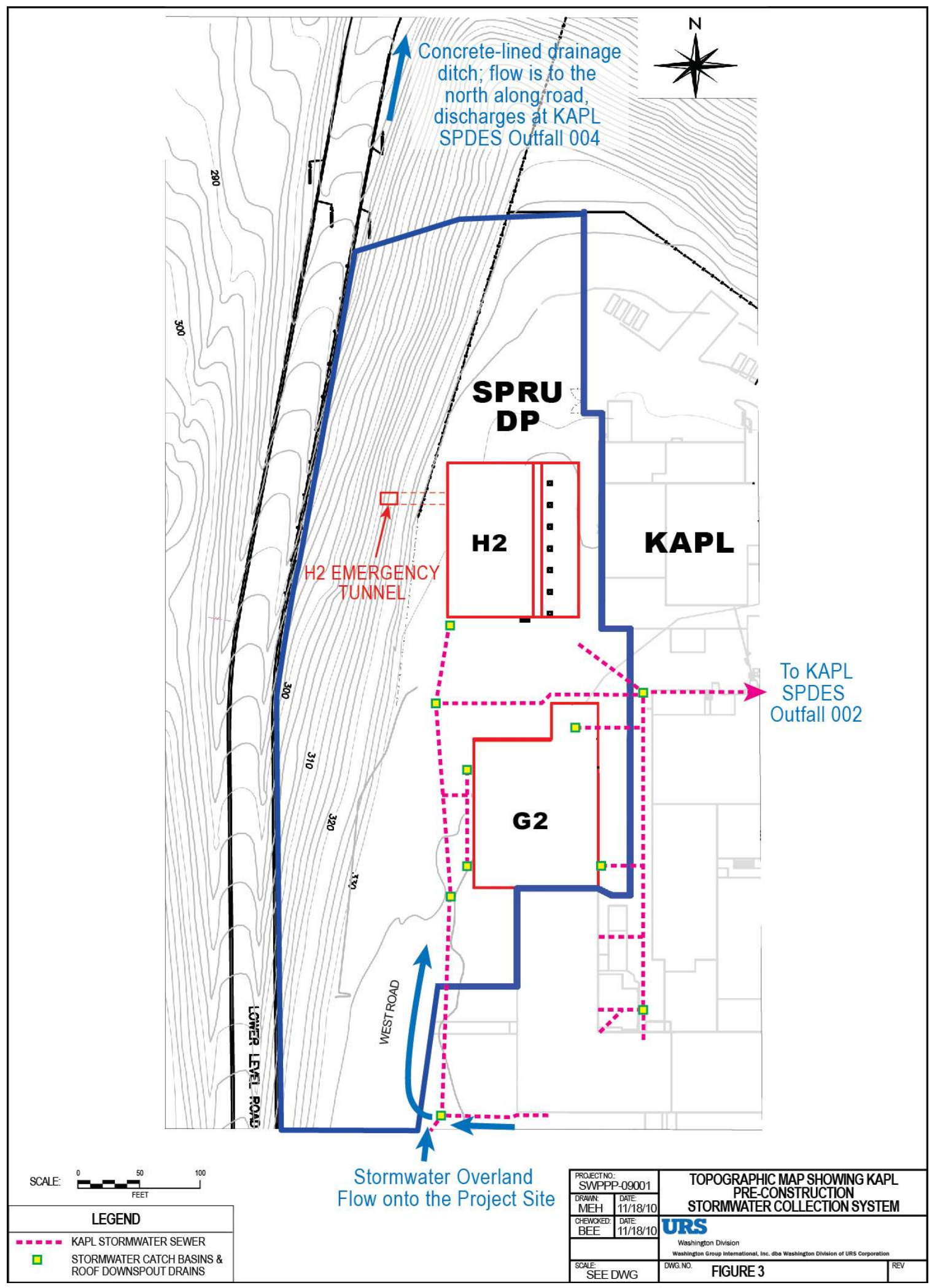

Figure 1. Stormwater management system prior to D\&D activities (Source: Figure 3 URS, 2011). 


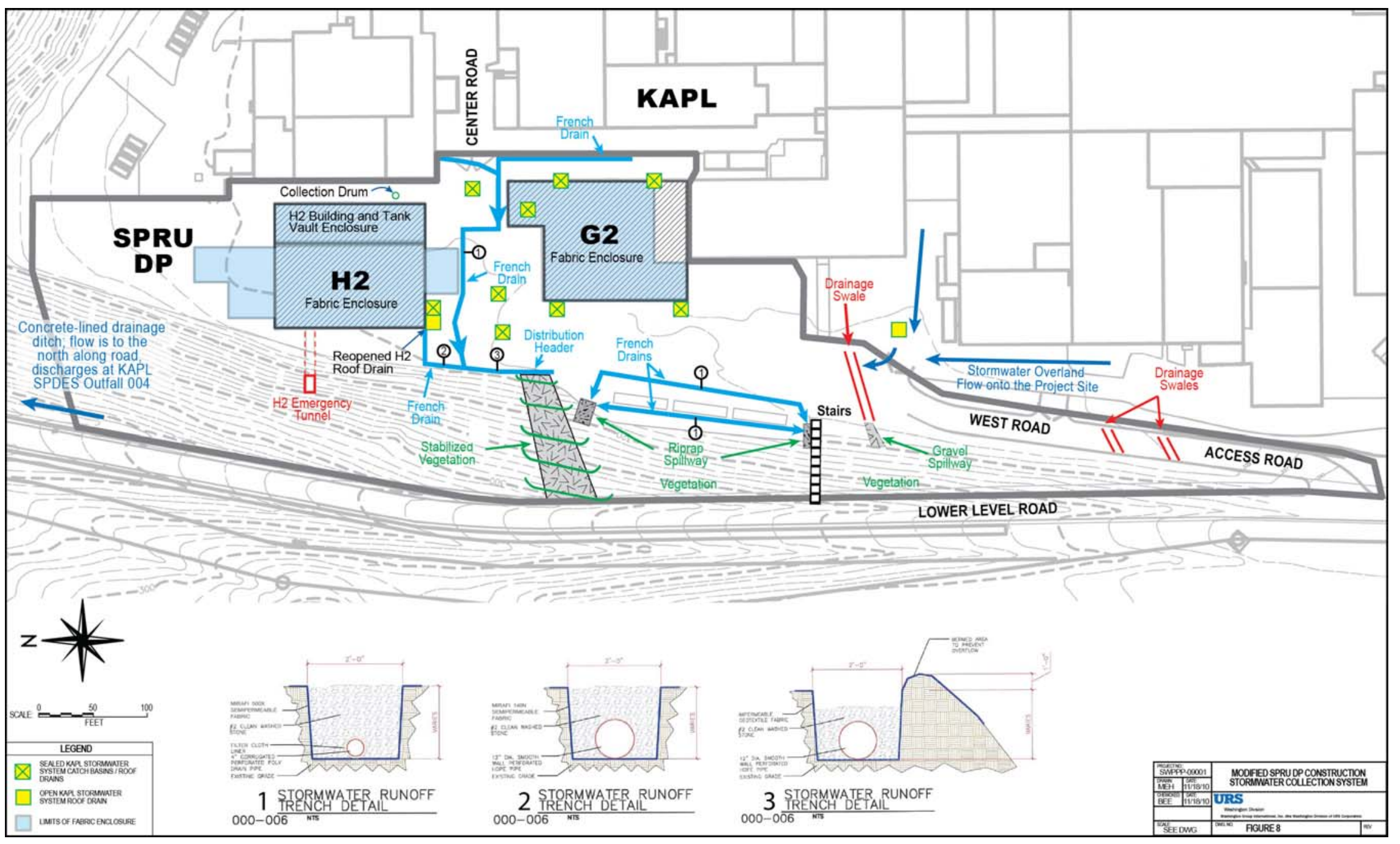

Figure 2: Configuration for D\&D prior to excavation to remove subgrade structures (Source: Figure 8 URS, 2011). 


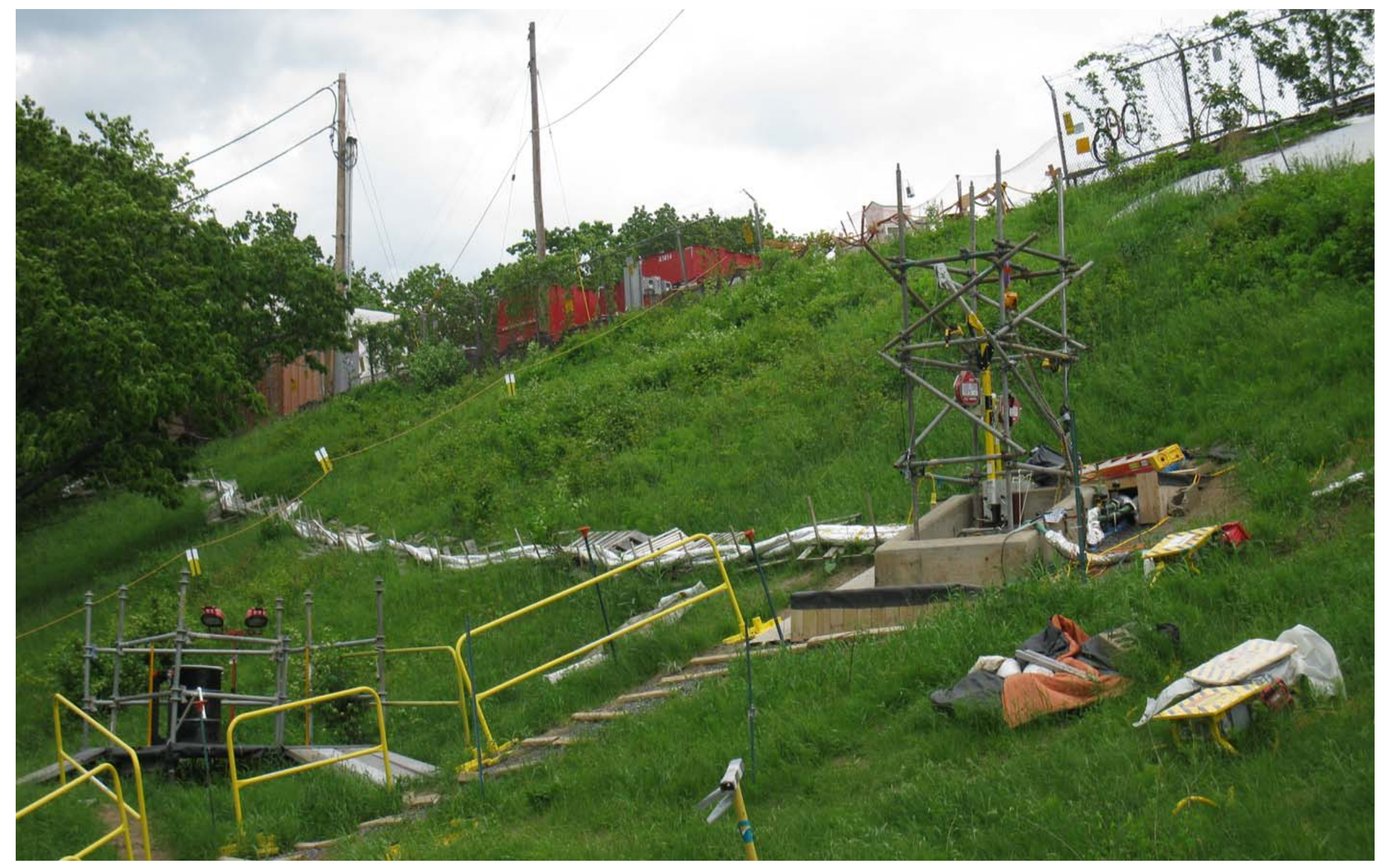

Figure 3: Present condition of the Hillside sump and storage tanks (May 25, 2011). 


\subsection{Configuration of Stormwater Management Prior to D\&D}

Figure 4 diagrams the flow of stormwater prior to D\&D activities. The majority of the precipitation that falls on the roofs and pavement around Buildings G2 and H2 is collected using a network of retention basins (storm sewer type structures) and directed to the KAPL storm sewers (Figure 1), which then discharges to SPDES Outfall 002. In addition, water that falls on the grassy western hillside is routed north for discharge at SPDES Outfall 004. For clarity, Figures 4 through 7 do not illustrate the stormwater that falls directly on the western hillside because it has not been processed with any of the infrastructure at the SPRU facility.

Around buildings G2 and H2, some of the precipitation percolates through the surface to reach the footer sump around Building $\mathrm{H} 2$, and this drains via gravity to the Hillside sump, where it is pumped back to the basement of Building $\mathrm{H} 2$ for treatment. The Hillside sump water is passed through an existing ion-exchange system and the treated water is held in a tank for sampling and analysis prior to discharge to the KAPL storm sewer, with subsequent discharge to SPDES Outfall 002.

DOE personnel at the SPRU site indicate that historically 70,000 to 100,000 gallons a year were collected in the Hillside sump and transferred to the $\mathrm{H} 2$ basement for treatment. Given the surface area of the $\mathrm{H} 2$ and $\mathrm{G} 2$ footprints and the surrounding asphalt areas (URS 2011), and an annual precipitation of approximately 38 inches, the estimated volume of water going to the KAPL storm sewers around Buildings G2 and H2 (Figure 1) was 1,400,000 gallons a year. This suggests that prior to D\&D, less than one percent of the annual stormwater was collected in the Hillside sump and treated.

\subsection{Configuration Based on the Stormwater Pollution Prevention Plan}

Figure 5 depicts the management of water as described by the Stormwater Pollution Prevention Plan (SWPPP) (URS 2011), and Figure 2 illustrates the layout of the French drains. Precipitation that falls on the proposed tent structure over Building $\mathrm{H} 2$ will be transferred to the KAPL storm sewer through the old stormwater inlet on the SW corner of Building H2. Rainfall on the pavement will primarily be collected in the French drains and conveyed to the hillside slope to discharge at SPDES 004, but some of this precipitation may percolate and reach the isolated storm sewer system and discharge at SPDES 002. It is important to note that the French drain system uses a semi-permeable geofabric for the majority of the network, specifically for those sections in and around the G2 and $\mathrm{H} 2$ buildings.

The SWPPP describes precipitation generating wastewater in the Hillside sump and the excavations that will be created to remove the subgrade structures of G2 and H2. These wastewater streams, along with water that has collected in the basements of Buildings G2 and $\mathrm{H} 2$ from D\&D misting operations within the fabric enclosures, will be conveyed to holding tanks and shipped offsite for treatment and disposal. 


\section{$\underline{3.3 \text { Current Configuration for Stormwater Management }}$}

Figure 6 presents the current conditions of the stormwater management system based upon observations and interviews conducted May 23 - 25, 2011. Pathways not identified in the SWPPP but that are considered to exist based upon observations and document reviews are illustrated as dashed lines in Figure 6.

Precipitation that falls on the areas around the buildings at the SPRU site is directed primarily to the French drains, where it is delivered to the hillside slope for discharge at SPDES Outfall 004 (Figure 2). The H2 footer drains/Hillside sump and the H2 and G2 basements receive water from precipitation falling on and near the building footprints. Since the French drain system was installed with a semi-permeable membrane, it is very likely that a significant portion of the water gets diverted via percolation to the subsurface and some of this reaches the H2 footer drains, the KAPL storm sewer, and/or to the H2 basement during extreme precipitation events. Impervious mats placed on the ground surface east of the tank vault attached to Building H2 (Figure 2) are sloped into the east wall of the tank vault, and precipitation falling in this area is channeled into the $\mathrm{H} 2$ footer sump (Figure 8). In addition, since the previous impervious surface has been significantly altered, infiltration into the subsurface has likely increased. The increased infiltration interacts with residual VOCs and radionuclides in soil and gravel beneath the surface and reaches the Hillside sump via the H2 footer sump. The additional VOC constituent prevents disposal of wastewater to the KAPL storm sewer since the H2 treatment system does not address these constituents.

Wastewater in the Hillside sump is pumped to Tank Cluster A, where it may be treated and then shipped to the DuPont facility in NJ or directly shipped as untreated water to PermaFix NW. Precipitation falling on the exposed interior portions of Buildings G2 and $\mathrm{H} 2$ is collected in the respective basements and pumped to Tank Cluster B, where it is sampled, analyzed and shipped untreated to PermaFix NW.

Important stormwater management observations are presented on Figures 9 through 17. The photographs were taken on the morning of May 25, 2011 by a DOE SPRU representative at the direction of members of the review team. The documented surface conditions are considered to have a significant impact on the amount of wastewater that is generated during storm events.

- $\quad$ On the east side of the Building H2 tank farm (Figure 8), a construction access corridor has been created and covered with an impervious surface - probably to prevent erosion and provide traction for movement of equipment. The "swamp mats" channel runoff to the right on Figure 8, which is into the footer drains around Building $\mathrm{H} 2$ that drain to the Hillside sump. Improved grading should be incorporated with the "swamp mats" to direct stormwater away from the H2 footer drain collection system.

- $\quad$ The west side of Building G2 (Figure 9) has approximately 50\% of the façade removed and roof drains have been disconnected from KAPL storm sewer and 
rerouted as surface runoff (light blue piping in lower right corner). Missing façade allows precipitation to enter the facility, which then has to be managed as wastewater. Temporary siding should be installed on Building G2 to minimize the entry of stormwater into the facility.

- The east side of Building G2 (Figure 10) has approximately 67\% of the façade removed, and the roof drains drain have been disconnected from KAPL storm sewer and rerouted as surface runoff (black piping in lower left right corner). Missing façade allows precipitation to enter the facility, which has to be managed as wastewater. Although nearly static levels in the basement of G2 indicate that this may be a problem only for large precipitation events.

- $\quad$ The section of missing roof (approximately 16\%) from Building G2 (Figure 11) allows direct stormwater loading to the interior of facility during precipitation events, which produces wastewater. The roof was removed to mechanical separate Building G2 from active KAPL facilities to the south (left in Figure 11). As shown by white tarps in the center of the building, temporary coverings have been placed to reduce infiltration into the basement. Using temporary covers over the open roof section to prevent precipitation from entering the contamination area would be a better stormwater management practice.

- The roof drains from Building G2 have been rerouted from the KAPL storm sewer to the French drain system as surface runoff (black pipe on Figure 12). Once the pipe exits the facility it is directed along the land surface to the French drain network, which is generally identified and located based upon the course, rounded river stone (right side of Figure 12). According to the SWPPP, the section in Figure 12 was constructed using a semi-permeable membrane. This is an area of concern because it allows water to percolate into the subsurface where it interacts with residual VOCs and radionuclides before reaching the $\mathrm{H} 2$ footer drains as wastewater. Improved management of stormwater from roofs could be accomplished by collection and reuse of roof stormwater (i.e. supplement misting water).

- Figure 13 shows the alteration of the surface between Building G2 and H2 with the crush and run gravel (smaller grey stone on left) and the French drain (coarse river stone on right). Also shown on the extreme right is a portion of the original asphalt surface that existed across all areas prior to D\&D activities. The removal of the asphalt and installation of French drain has increased infiltration to the subsurface, creating larger volumes of contaminated groundwater that emerge in the $\mathrm{H} 2$ footer sumps.

- The covered debris piles on the Building H2 pad are shown on Figure 14. The tent enclosure over the vaults holding the radioactive waste tanks is shown on the right. Stormwater currently falls on the exposed pad and flows from the tent surface into the basement where it collects as radioactivity wastewater. Improved management is needed to prevent "clean” stormwater from inadvertently entering 
basements of the buildings. There is currently a proposal to provide a larger structure over the $\mathrm{H} 2$ facility, and his structure should eliminate stormwater infiltration into the basement of the facility.

- Figure 15 presents the south equipment entrance to the enclosure that was installed over the tank vault associated with Building H2. An area of concern is the slope covered with impervious "swamp mats" that direct stormwater to the footer drains and possibly into the tank vaults and/or H2 basement. In evaluating the design and construction of an enclosure over the $\mathrm{H} 2$ building, consideration to access points like this need to be considered and appropriate precipitation coverage should be provided.

- Figure 16 presents the north end of the enclosure that was installed over the tank vault and engineered barriers associated with the excavation. Observe that, in general, the land surface slopes from Building G2 in the background toward Building H2. While a thick layer of gravel has been placed around the perimeter of the excavation (note height on right end of jersey bouncer) to direct water to the French drain system, it is likely that a significant amount of stormwater enters this excavation during precipitation events (observations during a precipitation event can verify this). The SWPPP incorporates an inspection program as Attachment 4, which is performed by SPRU DP. However, the focus of the inspection program is on discharge requirements relating to compliance with NYSDEC requirements and not on generation of wastewater from stormwater. In addition to satisfying regulatory requirements, the stormwater management program should incorporate inspections from SPRU contractors that consider excess wastewater generation from stormwater events.

- Figure 17 presents a roof drain that is located at the northwest corner of Building G2. The roof drain has been disconnected from the KAPL storm sewer and is routed as surface runoff to the French drain system. As previously discussed, an opportunity may exist to collect this stormwater and either reuse (i.e. for misting and dust control) or dispose as clean water offsite. Consideration should be given to point source collection, capitalizing on the concept of rain barrels and cisterns. As a rule of thumb, a 1,000 square foot roof will generate 625 gallons of rain during a 1" storm event. Small palette sized intermediate bulk containers (totes) are available in nominal sizes of 300-gallons and are readily transported with standard equipment and can be stacked. Additional details and considerations are discussed in the New York State Stormwater Management Design Manual (NYSDEC, 2010).

\subsection{Contractor Proposed Stormwater Management Strategy}

URS has proposed a stormwater management strategy to handle the surface water when D\&D activities are restarted. This system is presented on Figure 7. Precipitation falling on the proposed tent structure over Building $\mathrm{H} 2$ will be transferred to the KAPL storm sewer through the old stormwater inlet on the SW corner of Building H2. Rainfall on the 
pavement will primarily be collected in the French drains and conveyed to the hillside slope to discharge at SPDES 004.

Precipitation will also generate wastewater in the Hillside sump and the excavations that will be created to remove the subgrade structures of G2 and H2. These wastewater streams, along with water that has collected in the basements of Buildings G2 and H2 from D\&D misting operations within the fabric enclosures (and later from rain when the fabric enclosures are removed), will be conveyed to holding tanks and processed through a proposed ion-exchange and VOC treatment system. Most water is expected to be treated to a level that would allow percolation of the water into the abandoned rail bed, but this requires approval from the State of New York and the treated water may be shipped to DuPont NJ during the approval process. Some of the contaminated water from the basement may be directly shipped offsite if the contaminant levels are too high for efficient treatment.

\subsection{Recommendations to Improve the Stormwater Management Strategy}

As illustrated on Figures 5 through 17, there are differences in the stated management practices in the SWPPP, present observed conditions on the site, and the proposed stormwater management strategy with the new treatment system. The SWPP (Figure 5) and the proposed management strategy (Figure 7) do not account for wastewater generation from precipitation percolating through the broken up asphalt and semipermeable geotextile at the base of the French drains (Figures 2, 12 and 13) and surface runoff directly into the perimeter of Building H2 (Figures 6 and 8). These undesirable conditions allow the French drains to leak into the KAPL storm sewers and H2 footer sump, while the runoff east of Building $\mathrm{H} 2$ is directed into the perimeter of the tank vault and then into the $\mathrm{H} 2$ footer sump. The wastewater in the $\mathrm{H} 2$ footer sump drains to the Hillside sump, where it is pumped to Tank Cluster A for onsite treatment and shipment to DuPont NJ or direct shipment of untreated water to PermaFix NW.

Prior to D\&D activities, approximately 70,000 to 100,000 gallons of wastewater were processed each year (personal communication from SPRU DOE personnel). Presently, between November 2010 and May 25, 2011 (7 months), 365,000 gallons of wastewater has been processed for shipment offsite. Extrapolated to one year of operation, this equates to 626,000 gallons of wastewater that may be produced for one year of D\&D, versus 100,000 gallons before $\mathrm{D} \& \mathrm{D}$. The increase in wastewater is greater than a factor of 6 over pre-D\&D conditions, indicating stormwater management practices should be improved to lower the generation of unnecessary wastewater.

Over the 7 month period of November 2010 through May 2011, approximately 26 inches of rain fell (NOAA data for Albany, NY) on the G2 and H2 footprints and surrounding area (59,000 sq ft; per SWPPP). This equates to about 956,000 gallons of water, and 365,000 gallons of this was collected and shipped as wastewater. Therefore, under present conditions, approximately 38 percent of the precipitation ends up as wastewater (i.e., 365/956) versus less than 1 percent prior to D\&D. 
The D\&D schedule indicates that all contaminated debris and soil will be removed by the end of April 2012. Given a starting date of June 1, 2011, this is an 11 month period with the potential to generate 1,287,000 gallons of precipitation (59,000 sq $\mathrm{ft}$ times the estimated 35 inches of rain in 11 months). If stormwater management conditions remain the same, there is the potential to generate 489,000 gallons of wastewater ( 0.38 times $1,287,000)$. This is in contrast to the estimated 261,000 gallons of wastewater identified in WBS Level 6 cost account 14810.2.6.A.4.18x (Water Management - Disposition of treated/untreated water for offsite shipment), which is probably based on the proposed stormwater management strategy and not the current conditions. However, with the exception of placing an enclosure over the $\mathrm{H} 2$ foundation for 6 months and collecting the precipitation that falls on the enclosure roof for discharge to the KAPL storm sewer, there are no other changes indicated for the present French drain system. It appears probable that more wastewater will be generated than what is indicated in WBS Level 6 cost account 14810.2.6.A.4.18x.

Precipitation that presently falls on the exposed internal portions of Buildings G2 and H2 generates wastewater that collects in the basements of these structures. The SWPPP indicates that fabric structures will be placed over the existing exposed sections of Buildings G2 and H2 to minimize the generation of wastewater from falling precipitation until completion of $\mathrm{D} \& \mathrm{D}$ on the above-grade portions of the buildings, and the structure will then be open to precipitation when below-grade concrete walls are removed. During the enclosed operations, there will be wastewater generated inside the fabric structures from misting activity performed to minimize dust conditions during D\&D. The volumes of wastewater that will be generated from the misting operations and precipitation (after the fabric is removed and below-grade structures are excavated) were not found in the reviewed documents.

Based on the above observations, a detailed analysis should be performed to optimize the stormwater management system and the generation of wastewater from precipitation can be minimized by considering the following recommendations:

- $\quad$ Temporary siding and roof structures should be installed on Building G2 to minimize stormwater from entering the facility

- Strong consideration should be given to an enclosure over the entire H2 facility including the tank vault enclosure and access doors on north and south ends. This enclosure should reduce infiltration to $\mathrm{H} 2$ footer drains and basement.

- All areas around Building H2 and the Tank Vault should be sloped away from the structure to minimize the generation of wastewater from precipitation that enters the H2 footer sump, which drains to the Hillside sump.

- Impermeable geotextile should be placed under the French drains to eliminate percolation of stormwater into the H2 footer sump and KAPL storm sewer. 
- All surfaces that are not part of the French drain system should be made impervious to the infiltration of precipitation. The "swamp mats" or asphalt can be used as effective materials to create localized impervious surfaces. Current use of swamp mats east of the $\mathrm{H} 2$ tank farm can be improved with grading away from sensitive areas and, if cost effective compared to asphalt, use should be expanded to other areas of the site.

- The stormwater management program needs to incorporate inspections from SPRU contractors that consider excess wastewater generation from stormwater events.

- Onsite collection and storage of stormwater from roofs and enclosures should be considered to minimize loading to French drains and provide beneficial reuse of collected water. 


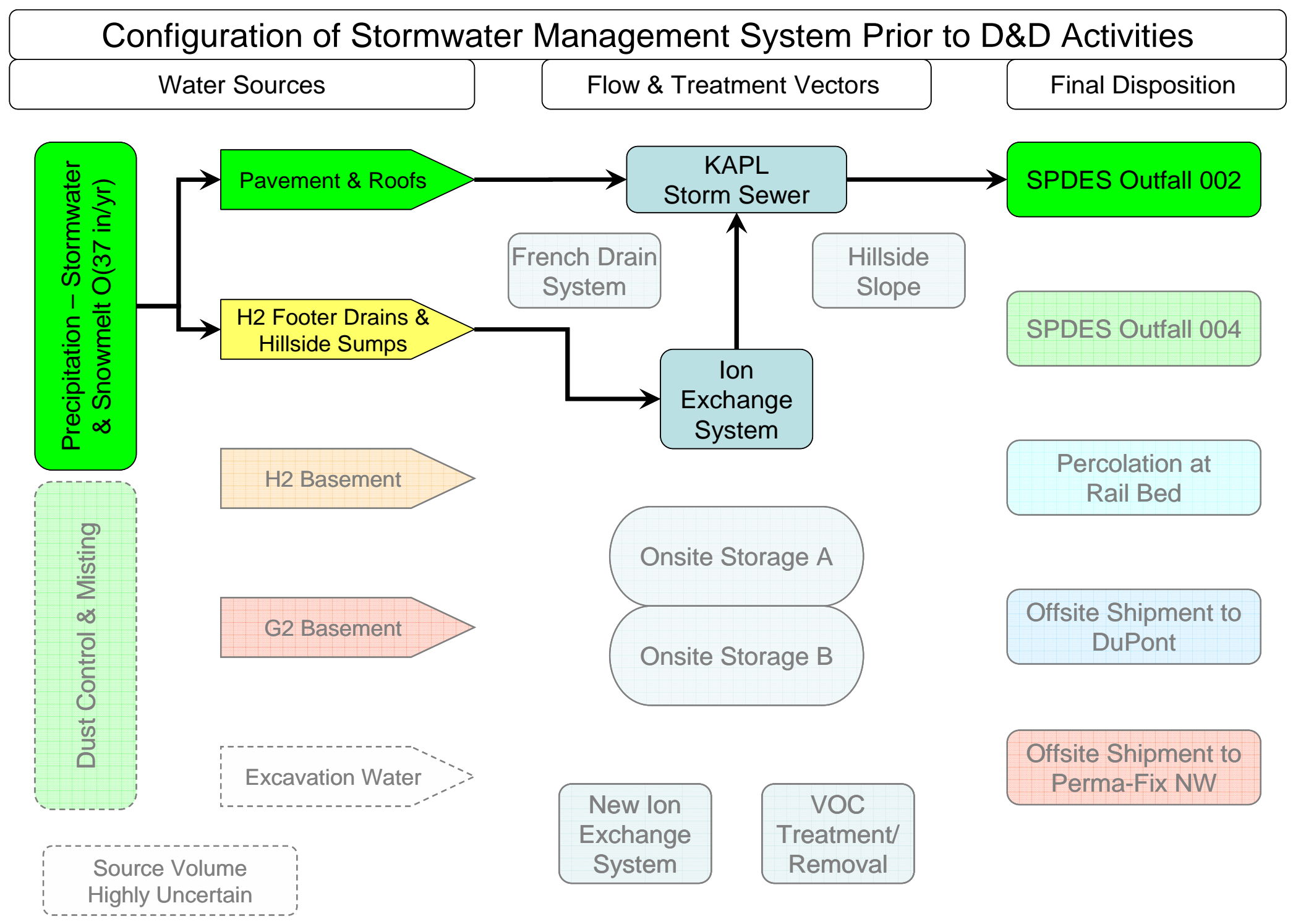

Figure 4: Configuration of the Stormwater Management System Prior to D\&D Activities. 


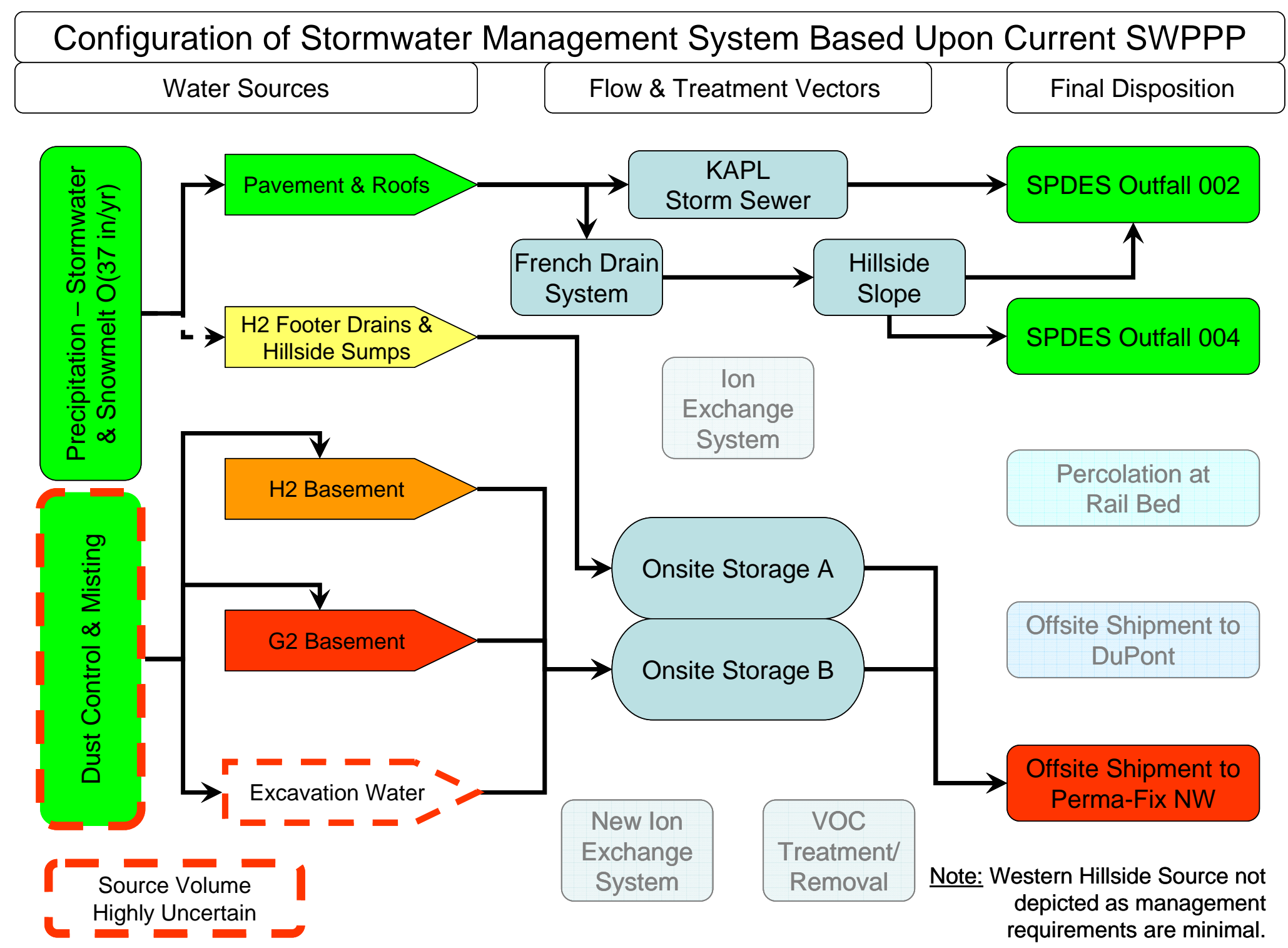

Figure 5: Configuration of Stormwater System Based Upon Current Stormwater Pollution Prevention Plan. 


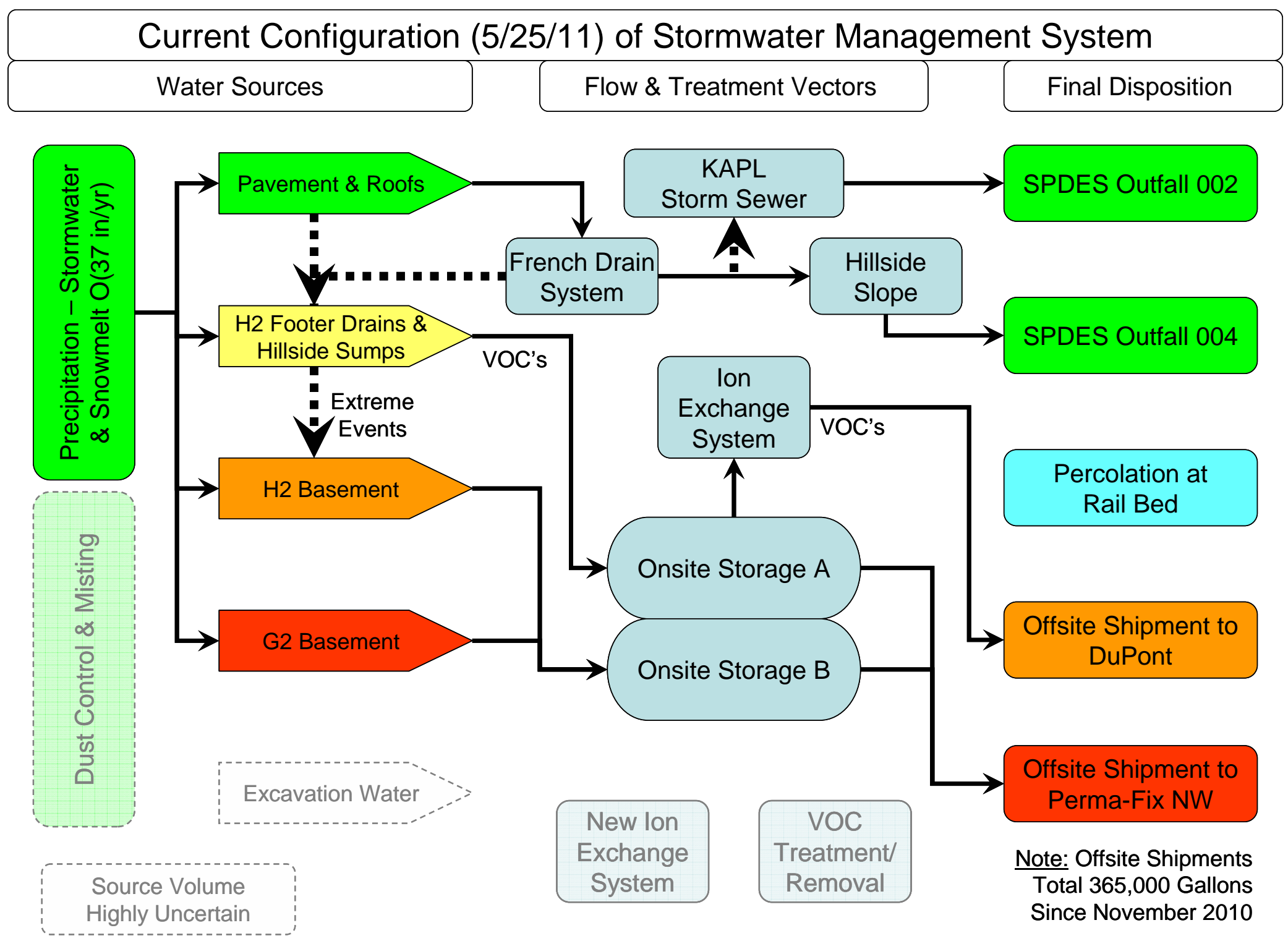

Figure 6: Current Configuration of Stormwater Management System (Observations May 23-25, 2011). 


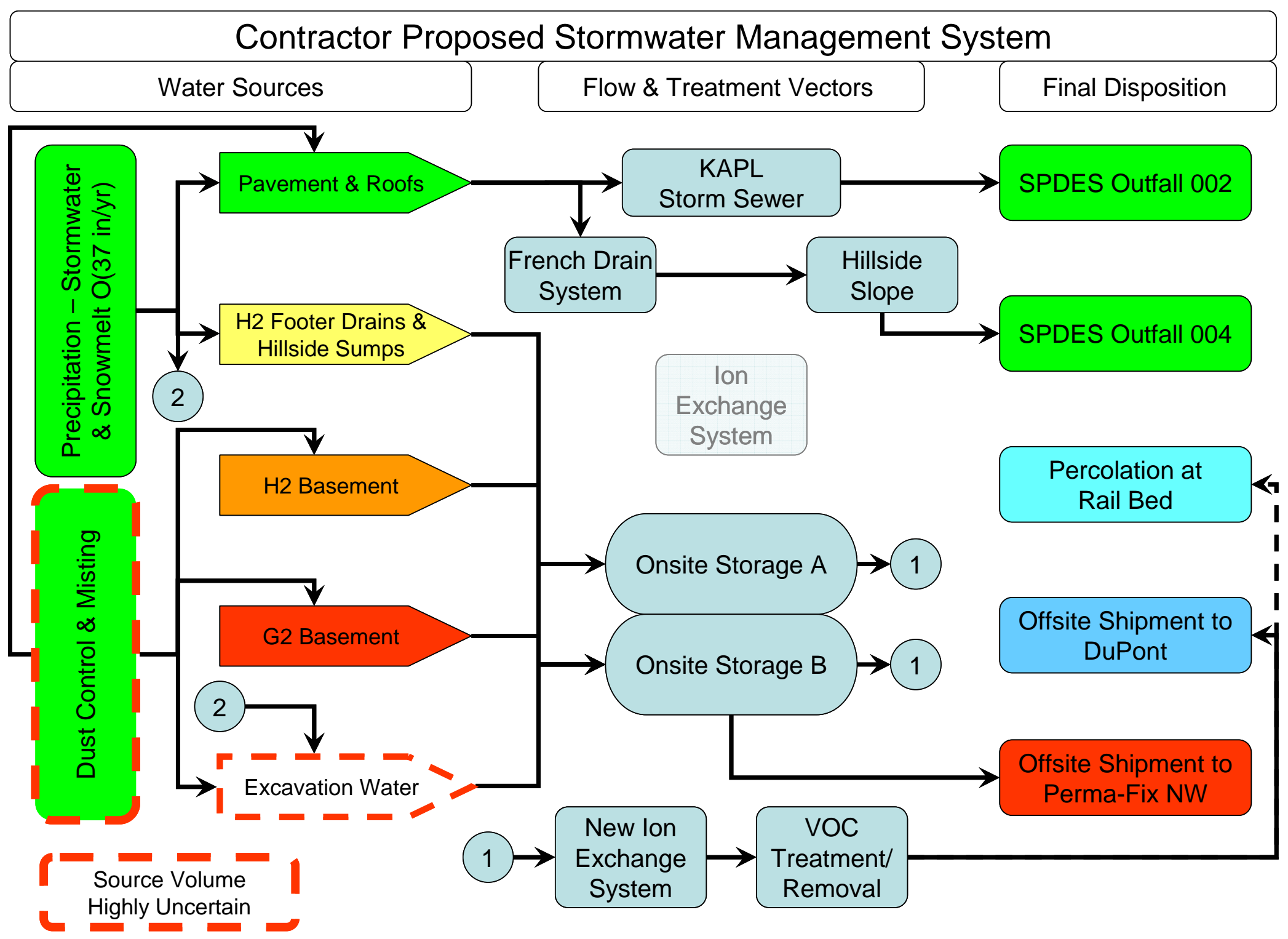

Figure 7: Contractor Proposed Stormwater Management System with Rail Bed Discharge. 


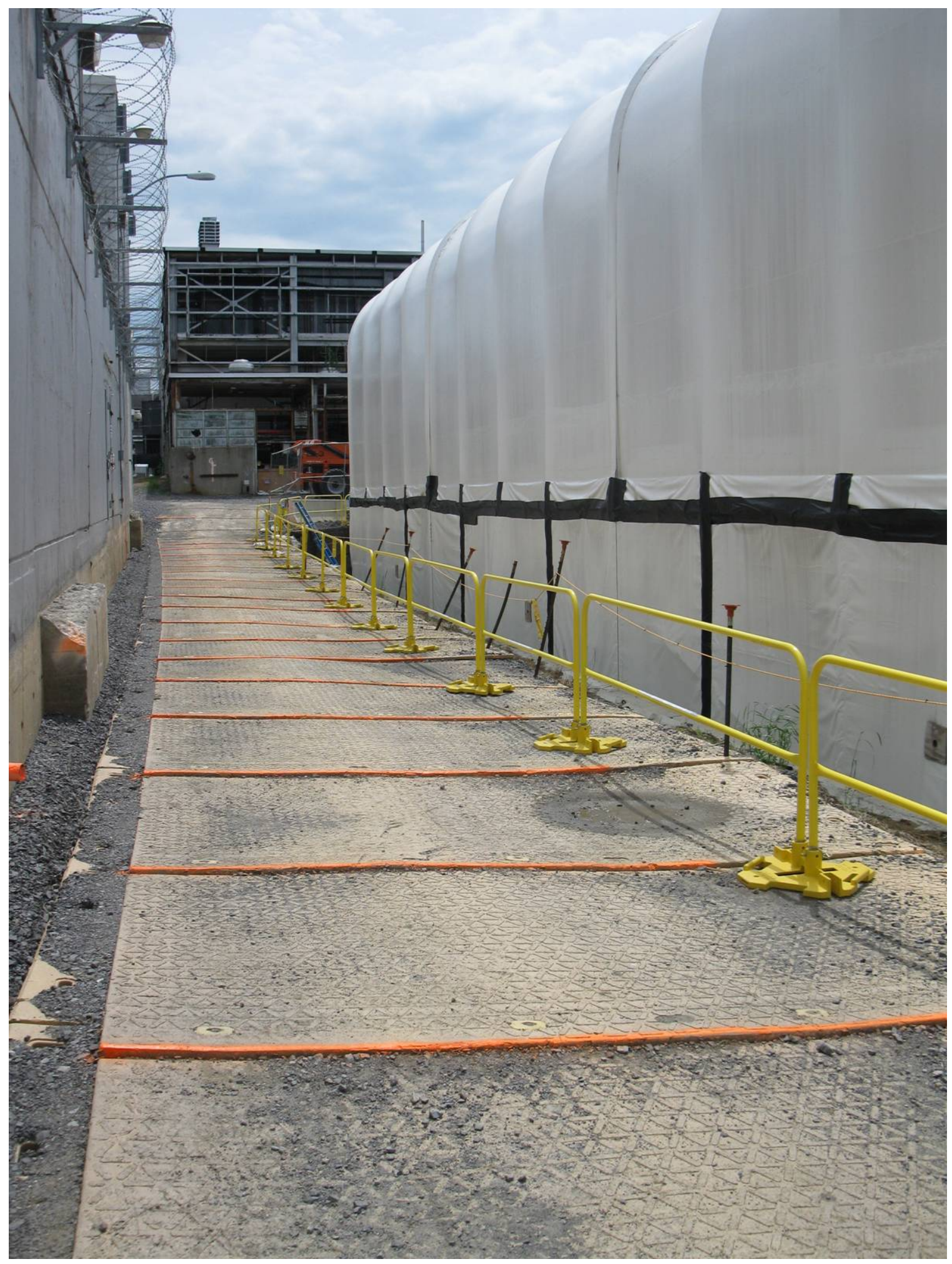

Figure 8: Observed Conditions East Side of Building H2. Temporary impervious surfaces (Swamp Mats) used as cover surface for access corridor. Grade slopes to the right towards Building H2. Also note north façade removed from Building G2 in the background. 


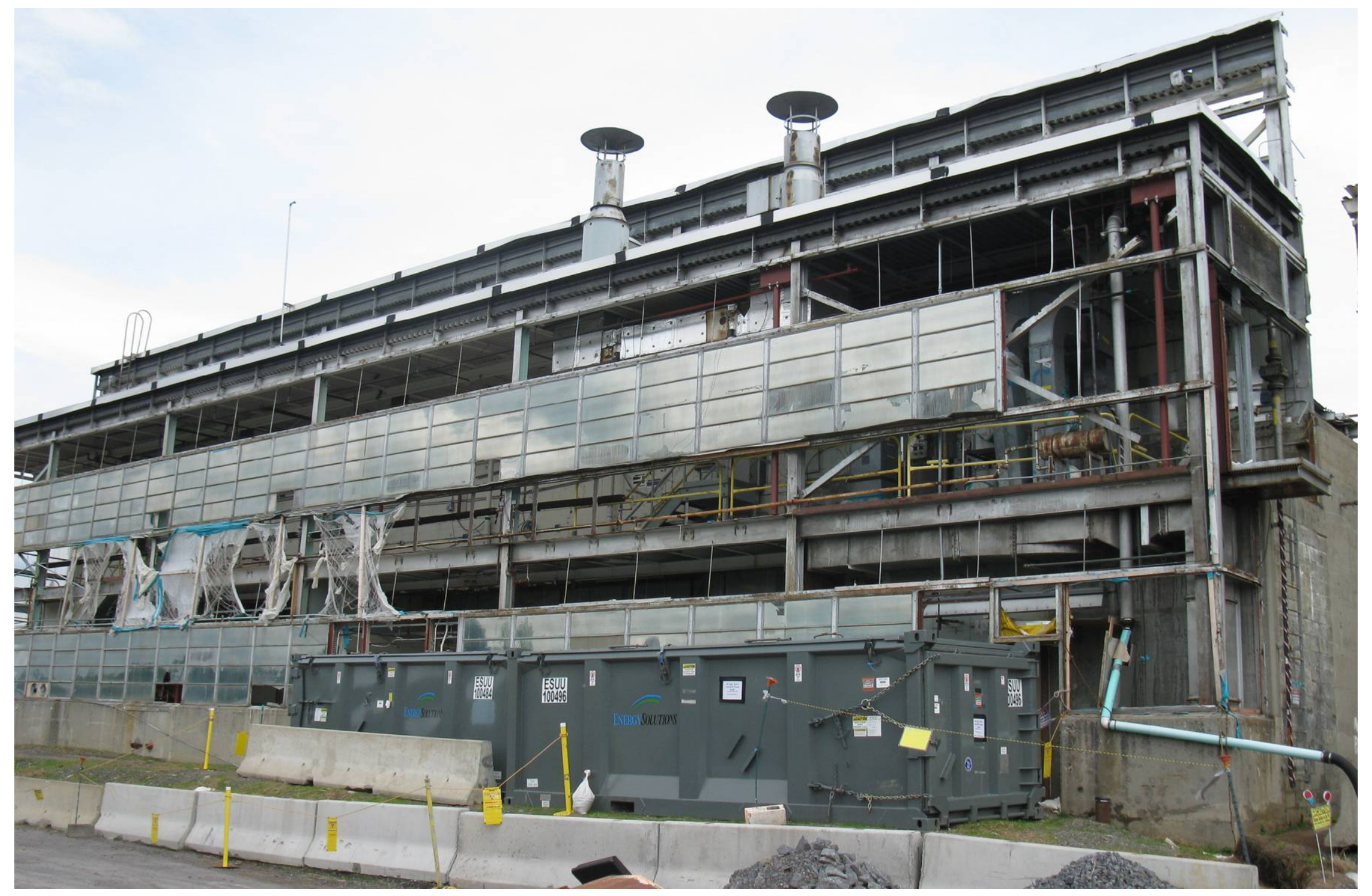

Figure 9: Observed Conditions of Building G2 (West Side) Note rerouted roof drain on right side. 
SRNL-STI-2011-00334

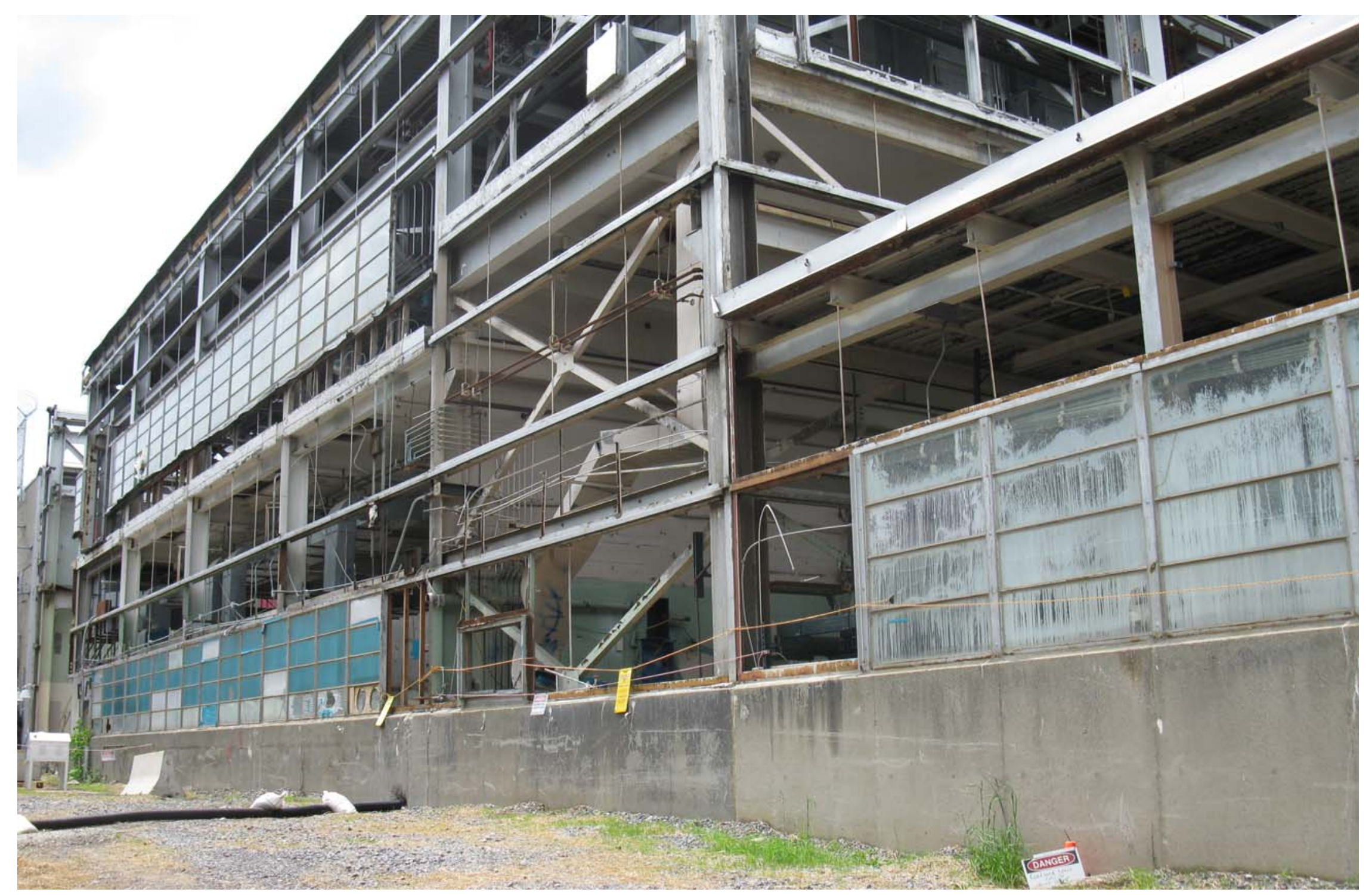

Figure 10: Observed Conditions of Building G2 (East Side) 


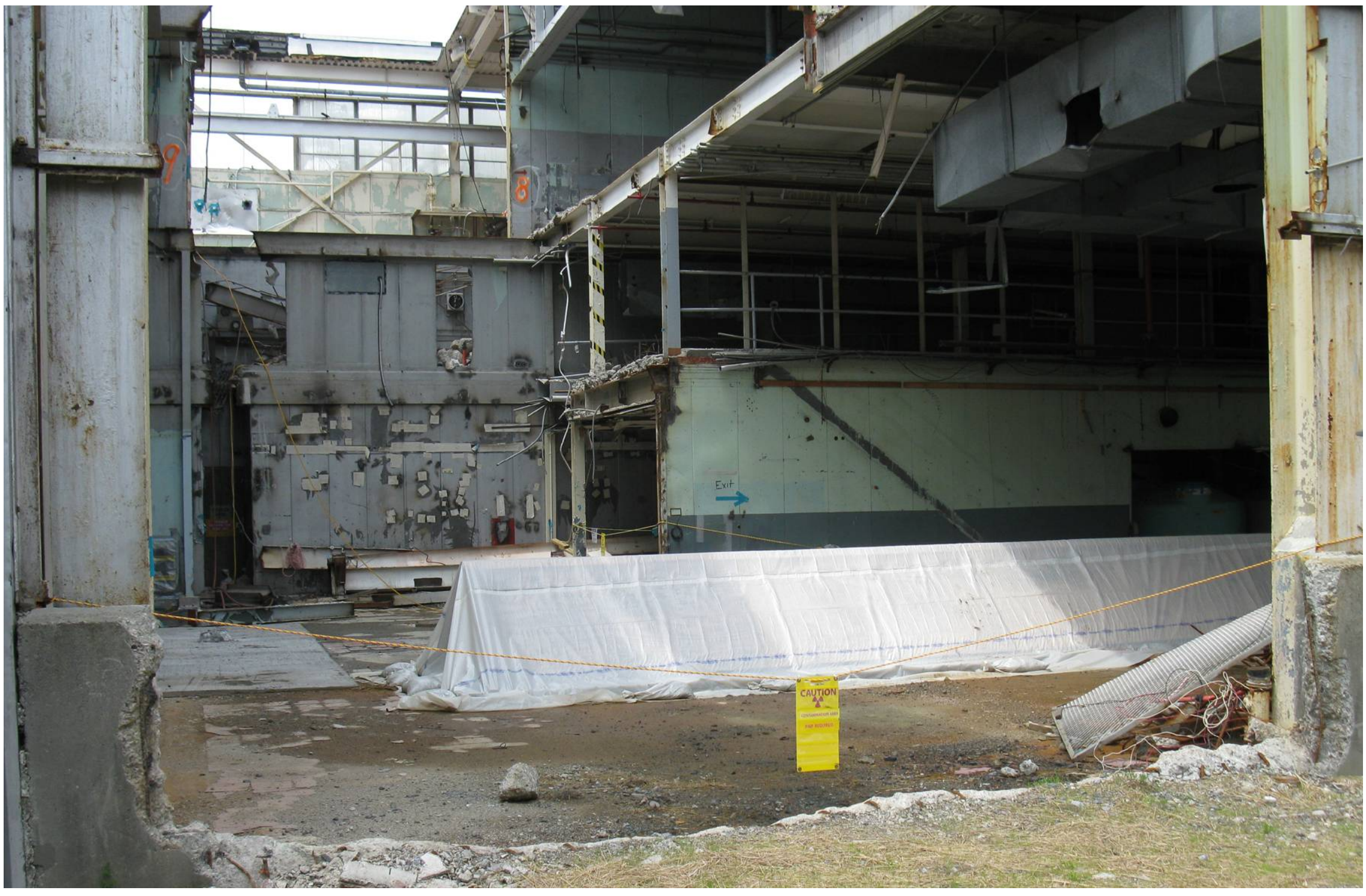

Figure 11: Observed Conditions of Building G2 (Southest Corner). Note missing roof section and evidence of water on floor. 


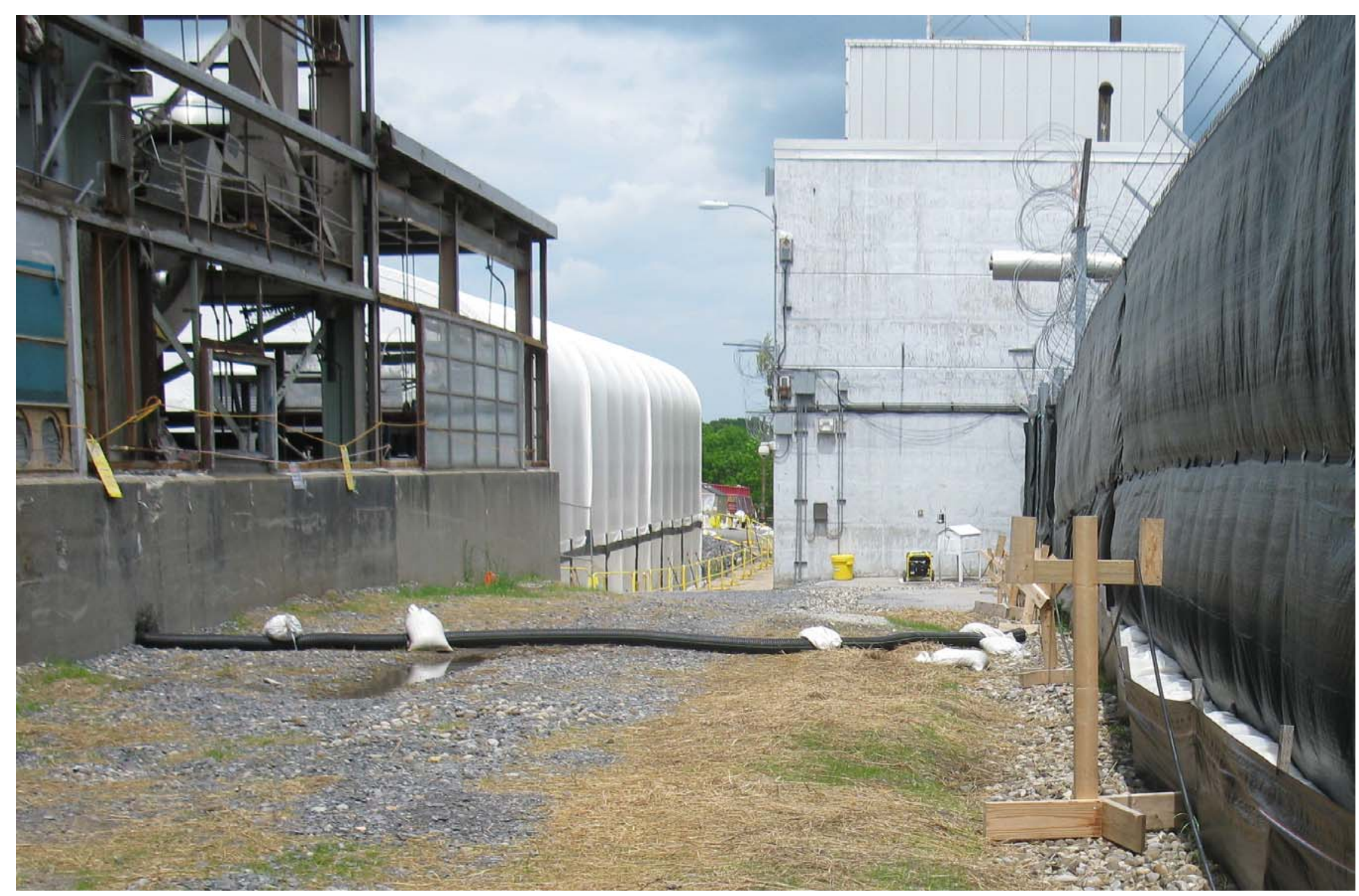

Figure 12: Observed Conditions of Building G2 (East Side). Note routing of roof drain to installed French drain system on right. 


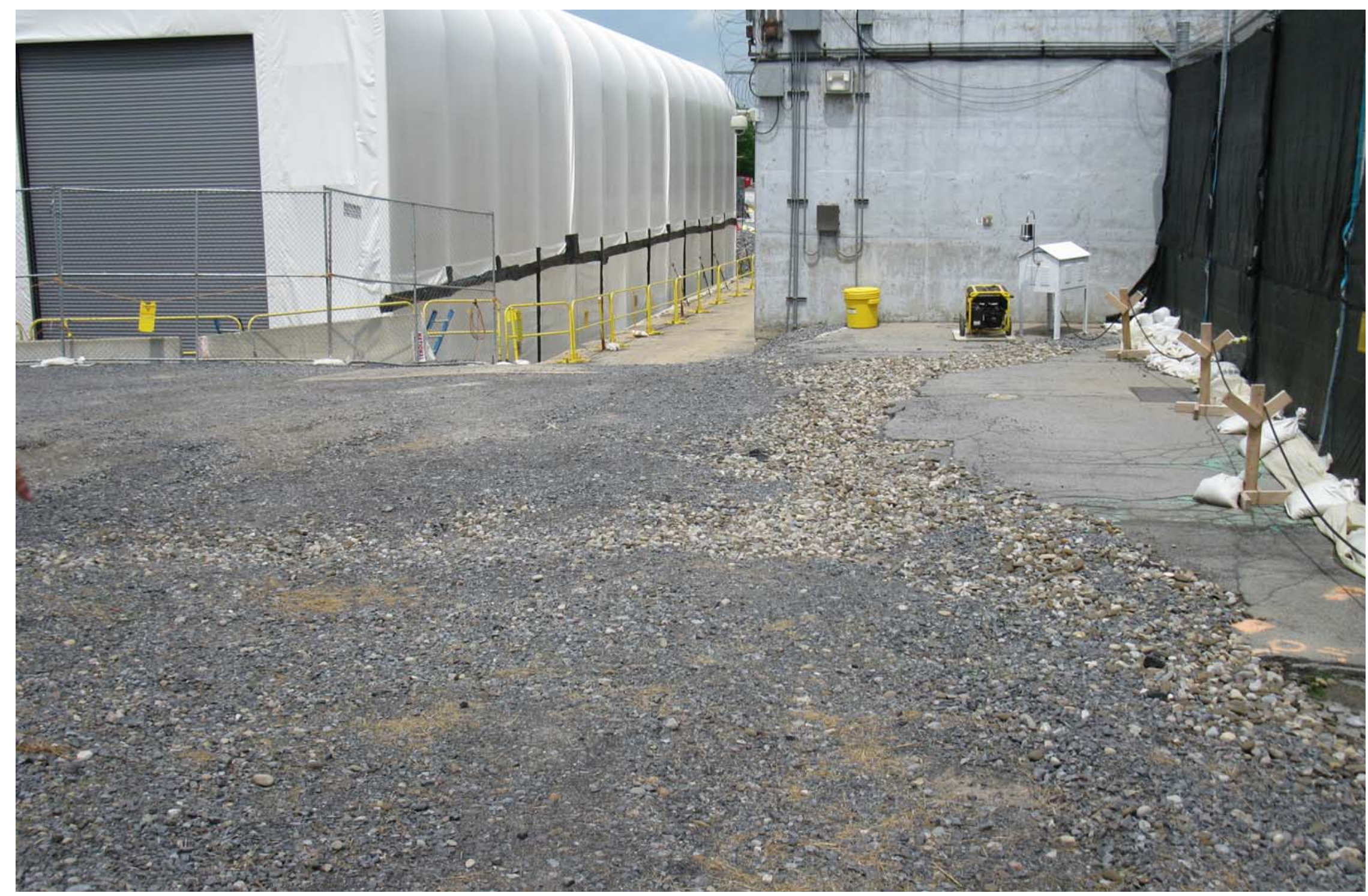

Figure 13: Observed Conditions between Building G2 and H2 showing French drain (coarse stone) and alteration of surface from impervious asphalt on right to crush and run gravel on left. 


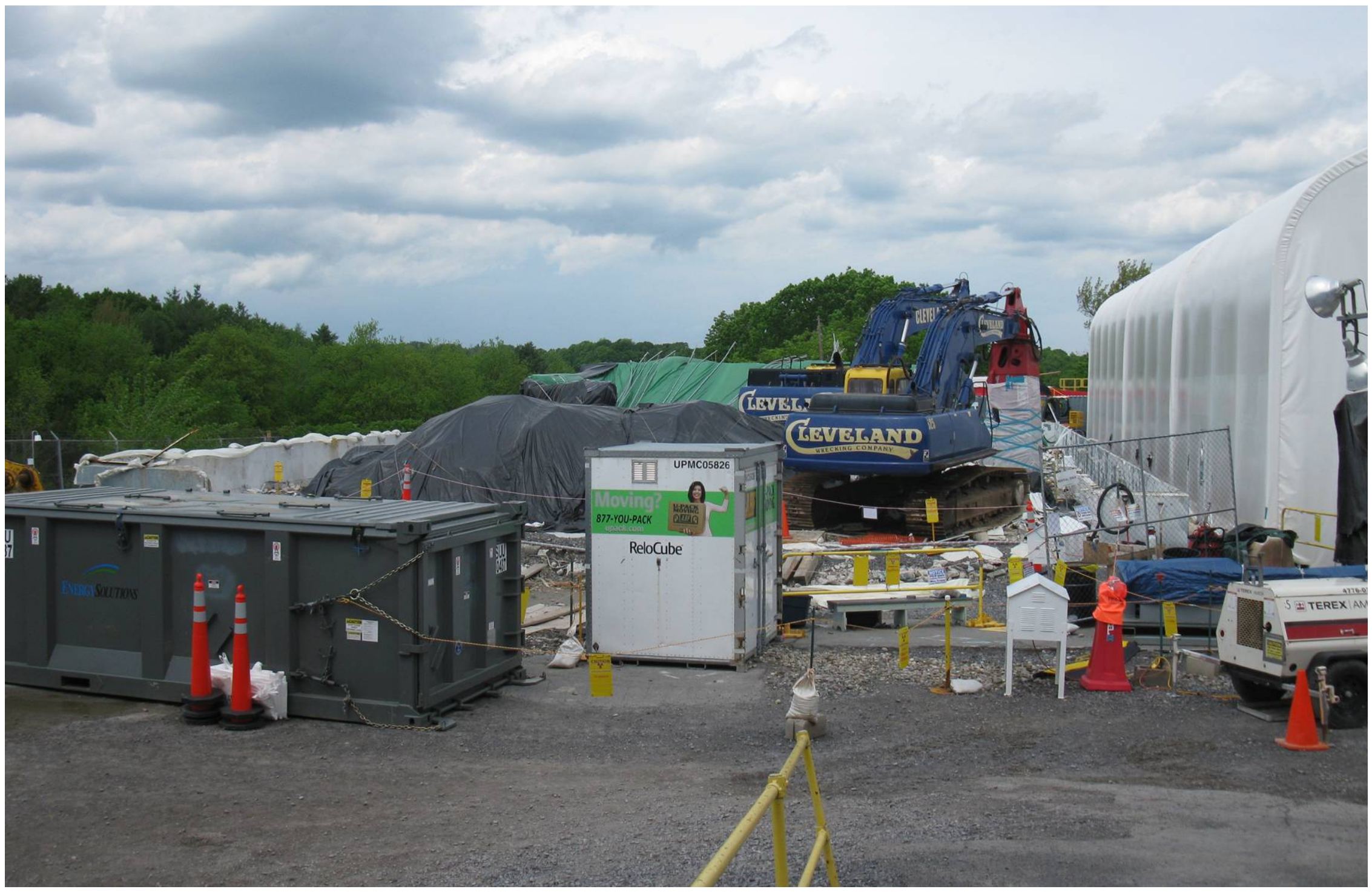

Figure 14: Observed Conditions of Building H2 showing demolition to grade (looking North from G2). 
SRNL-STI-2011-00334

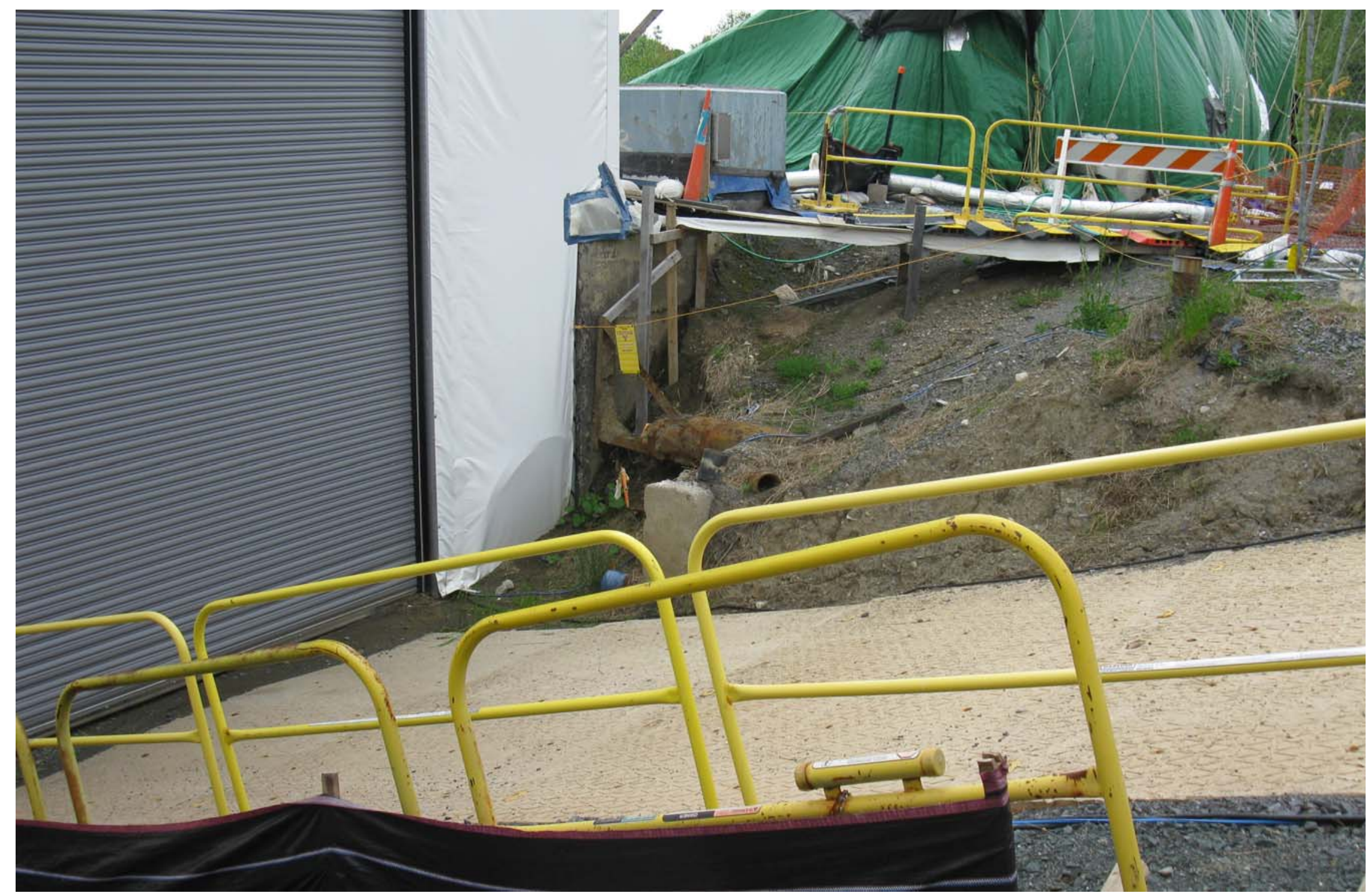

Figure 15: Observed Conditions North End of Building H2. Entrance to Tank Vault enclosure. Slope is covered with impervious "Swamp Mats" that increases precipitation runoff to H2 Footer drains. 


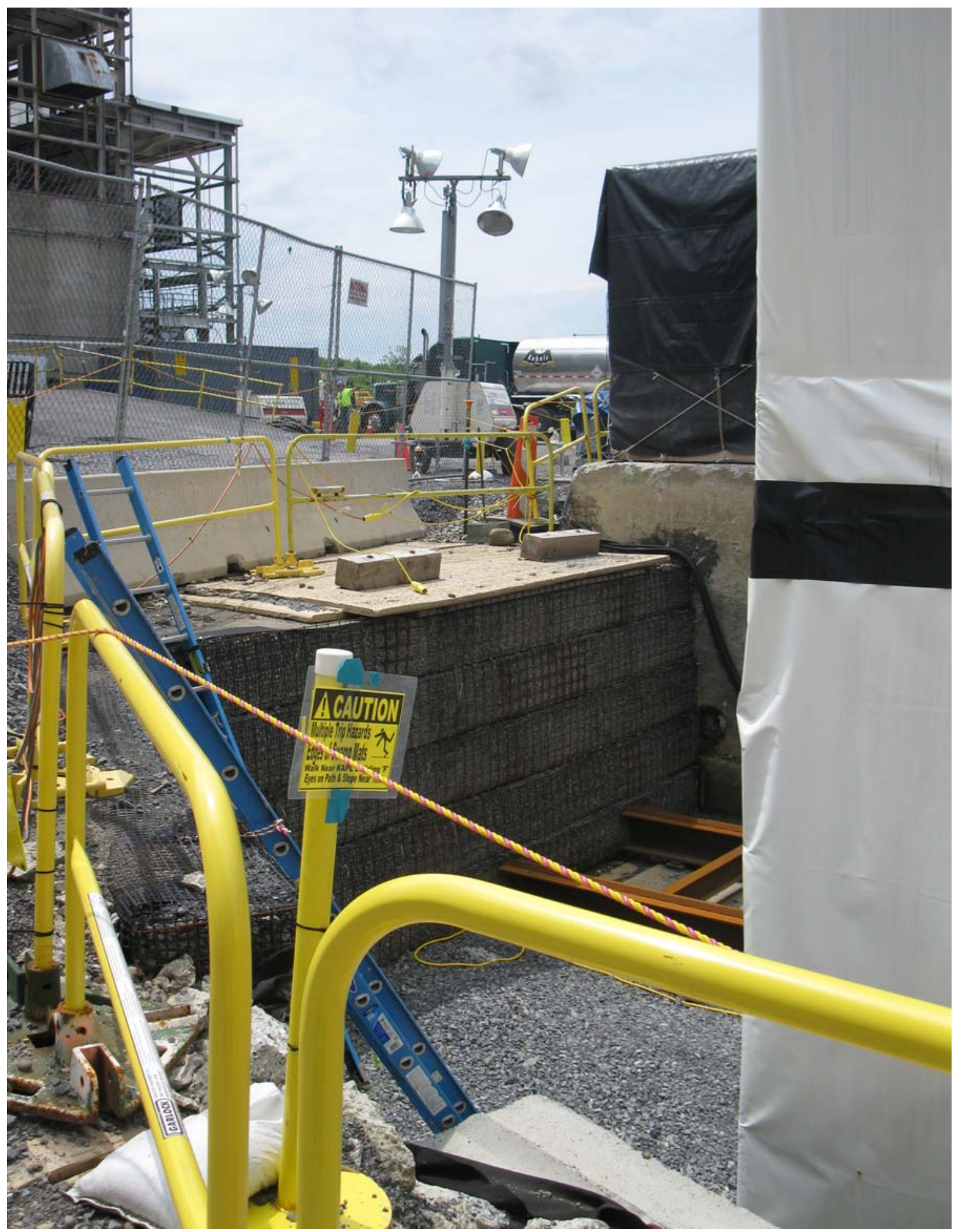

Figure 16: Observed Conditions of the Southern End of the Tan Vaults. Significant potential for infiltration to $\mathrm{H} 2$ Footer drains during extreme precipitation events. 
SRNL-STI-2011-00334

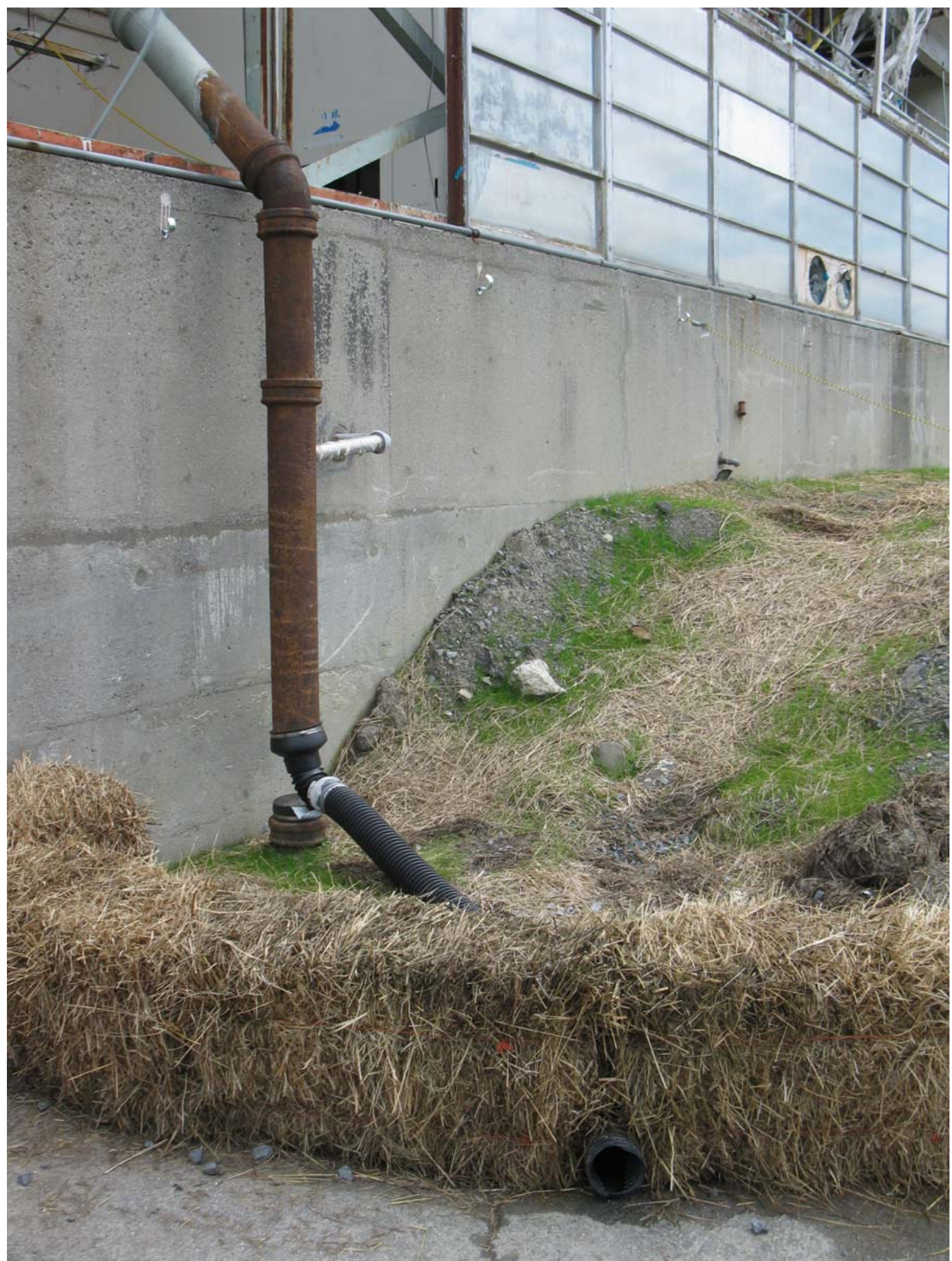

Figure 17: Roof drain on Building G2 isolated from KAPL storm sewer and routed as surface drainage to French drain system. 


\subsection{Stormwater Treatment Systems}

\subsection{History of the Stormwater Treatment System}

Prior to D\&D activities, the stormwater treatment system was housed in the basement of Building $\mathrm{H} 2$ and operated at a nominal capacity of five to eight gpm. Precipitation events during a calendar year delivered 70,000 to 100,000 gallons of water to the $\mathrm{H} 2$ footer sump (personal communication from DOE-SPRU personnel), which sent the stormwater to the hillside sump collection point where it was pumped to the basement treatment system to remove radionuclides (primarily Sr-90 and Cs-137) and then transferred to a holding tank. Samples of the treated water were collected and sent to the KAPL analytical laboratory to demonstrate that radionuclide levels were low enough to discharge the treated water to one of KAPL's permitted stormwater discharge points (SPDES 002, see Figure 1).

In the spring of 2010, the SPRU site was prepared for D\&D of Buildings H2 and G2. Prior to commencing D\&D work on Building H2, the stormwater treatment system was moved from the basement to a compacted gravel pad north of Building $\mathrm{H} 2$ and transfer lines were installed from the hillside sump over the ground surface to holding tanks placed adjacent to the treatment system. Three holding tanks (nominal capacity of 18,000 gallons each) held the stormwater discharged from the hillside sump, and two tanks (2,900 gallons each) held the treated water. The system was operated at a nominal capacity of 5 to $8 \mathrm{gpm}$ and samples of the treated water were collected, analyzed and discharged following the same protocols used when the system was in the basement of Building $\mathrm{H} 2$.

Two additional holding tanks (nominal capacity of 18,000 gallons each) were staged in the area north of Building H2 to hold stormwater collected in the basements of Buildings H2 and G2 during demolition activities. Radionuclide levels in the water collected in the basements are higher than levels observed for the hillside sump water because of the interaction of the precipitation with contaminated equipment and debris within the building footprints.

In late September 2010, a D\&D activity on the H2 pad resulted in an air release of radionuclides from an evaporator tank, and D\&D activities were shut down to investigate the incident. Following the shut-down of D\&D activities, an unpermitted discharge of wastewater to the KAPL stormwater system resulted in KAPL's termination of the SPRU discharges of treated stormwater to KAPL's permitted outfall, and the treatment system was shut down while the SPRU contractor negotiated contracts for shipment and disposal of the contaminated stormwater. The initial contract to dispose of untreated stormwater was placed in November 2010, and a second contract for treated stormwater was put in place with DuPont in NJ. Treatment of the stormwater was restarted in March 2011, after the second contract was signed.

\subsection{Costs Associated with Stormwater Treatment, Shipping and Disposal}

Two shipping and disposal contracts are now established for the contaminated stormwater (i.e., wastewater). Most of the untreated wastewater is shipped to PermaFix NW in Richland, WA for treatment and disposal (approximately \$11/gallon; personal communication with DOE 
personnel), and some of the wastewater from the hillside sump is treated with the present ionexchange system (5 to $8 \mathrm{gpm}$ ) and shipped to DuPont's water treatment facility in NJ for disposal ( $\$ 4$ to $\$ 10 /$ gal, depending on the number of passes through the ion-exchange resin; personal communication with DOE personnel). Between November 01, 2010 and May 24, 2011, 345,000 gallons of wastewater were shipped offsite (URS shipping records), and approximately 90 percent of the wastewater was shipped untreated to PermaFix NW. This indicates that over $\$ 3,000,000$ has been spent on the disposition of untreated wastewater over the past seven months.

URS is proposing a new treatment system that will process a minimum of 20 gpm of wastewater at a nominal cost of less than \$1/gal (includes operation and maintenance of the system and resin disposal). Based on the information and cost in WBS Level 6 cost account 14810.2.6.A.4.18x (Water Management - Disposition of treated/untreated water for offsite shipment) there will be 224,000 gallons of treated water shipped by Viola to the DuPont NJ facility and 37,000 gallons of untreated water shipped to PermaFix NW over the period June 2011 to July 2012, at a total cost of $\$ 1,000,000$. If the cost to treat the water is about $\$ 1 / \mathrm{gal}$, then $\$ 224,000$ is for treatment and \$776,000 is for handling, shipping and disposal of the treated/untreated water (e.g., sampling and analysis to demonstrate compliance with waste disposal criteria, shipping documents, handling and loading the water onto tankers, shipping and disposal fees). The cost to purchase and construct the treatment system and associated piping and support facilities is found in WBS Level 6 account 14810.2.1.B.4.05x (Lower Level Rail Area), and it is estimated at \$1,766,000.

Therefore, if the new treatment facility is built, the present estimated cost to build the facility and treat and dispose of the 261,000 gallons of wastewater (expected to be generated between June 2011 and July 2012) is about \$2,766K (about \$10/gal). However, if the treated wastewater is disposed in the abandoned rail bed adjacent to the Mohawk River, the cost to treat and dispose of the stormwater is about $\$ 2,027,000$ (\$1,766,000 to build the new facility and about $\$ 261,000$ to treat the water), which is about $\$ 8 /$ gal. The treated water would have to meet disposal acceptance criteria established by the State of New York Department of Environmental Conservation prior to discharge to the rail bed, but discharge to the rail bed was approved by the State of New York for previous remedial work at the site, and such approval for the treated water would save substantial costs associated with transport and disposal of the water.

Another potential option that is not discussed by URS is the use of the present treatment system and disposal of the treated wastewater in the abandoned rail bed adjacent to the Mohawk River or at the DuPont NJ facility. Based on discussions with site DOE personnel, historic treatment of the hillside sump water in the basement of Building H2 and discharge to the KAPL stormwater system generated costs on the order of $\$ 1 /$ gal, similar to the cost proposed for the new treatment system. Additionally, relative to the proposed cost for the new treatment system $(\$ 1,766,000)$, it is probably a reasonable estimate of $\$ 2$ to $\$ 4 /$ gal $(\$ 500,000$ to $\$ 1,000,000)$ to upgrade the present system to increase capacity, remove VOCs and construct pipe lines to discharge the estimated 261,000 gallons of water to the abandoned rail bed (total of \$3 to \$5/gal for this option; \$2 to $\$ 4 /$ gal to modify system and an additional $\$ 1 /$ gal to treat). This cost would be expected to increase by about $\$ 2 /$ gal if the water was shipped to DuPont NJ, based on the analysis provided in the previous paragraph for the new treatment system. A summary of the estimated rates for the stormwater treatment and disposal options is provided in Table 3. 


\section{Discharge of Treated Water to the Abandoned Rail Bed}

The State of New York Department of Environmental Conservation must establish discharge criteria for contaminants in the treated wastewater prior to disposal in the abandoned rail bed. Discharge to the rail bed was approved by the State of New York for previous remedial work at the site, and such approval for the treated water would save substantial costs associated with transport and disposal of the water. However, the time for New York to establish the criteria and approve the discharge plan is unknown, and this creates a large uncertainty in the implementation of this option over the next year.

\section{Cost Comparison for Existing versus New Treatment System}

A cost comparison is needed to evaluate if it is more economical to modify the existing system and treat a smaller volume of wastewater (possible if stormwater management practices are improved to lower the volume of wastewater) or build the new system and process the wastewater at a faster rate.

Based on the observations and analysis presented in this section, the following recommendations are made:

- Improve the estimate on the volume of wastewater that will be generated by $\mathrm{D} \& \mathrm{D}$ activities, and account for better stormwater management practices to minimize this volume.

- Estimate the cost to modify the existing treatment system to process wastewater for disposal at the DuPont NJ facility or discharge to the abandoned rail bed.

- Given that lower wastewater volumes are possible, re-evaluate the requirement that a new treatment system must demonstrate a minimum process rate of $20 \mathrm{gpm}$.

- Compare the cost of modifying the existing system and purchasing and constructing a new system (with similar gpm rates for both systems) to determine the best value for DOE. 


\section{References}

NYSDEC (2010). New York State Stormwater Management Design Manual. Augusta 2010.

New York State Department of Environmental Conservation, 625 Broadway, Albany, NY 12233

SPRU Disposition Project, Cost and Schedule Basis of Estimate Form, WBS6:

14810.2.6.A.4.18x (Water Management - Disposition of treated/untreated water for offsite shipment).

SPRU Disposition Project, Cost and Schedule Basis of Estimate Form, WBS6:

14810.2.1.B.4.05x (Lower Level Rail Area).

URS (2011). Stormwater Pollution Plan (SWPPP) for the SPRU DP. Document ID SPRU-ENV002. Revision 8. March 18, 2011. URS, Niskayuna, New York 12309. 


\section{Appendix A: Technical Assistance Request}

\section{STATEMENT OF WORK}

Review of water management procedures at the Separations Process Research Unit (SPRU) on the Knoll Atomic Power Laboratory (KAPL), Niskayuna, New York. The landlord for KAPL is the Office of Naval Reactors.

\section{PURPOSE:}

The U.S. Department of Energy (DOE) is currently evaluating the water management procedures at the Separations Process Research Unit (SPRU). The facility has three issues related to water management that require technical assistance: (1) due to a excessive rainfall event in October, 2010, contaminated water collected in basements of G2 and H2 buildings As a result of this event, the contractor has had to collect and dispose of water offsite; (2) The failure of a sump pump at a KAPL outfall resulted in a Notice of Violation issued by the New York State Department of Environment and Conservation (NYSDEC) and subsequent Consent Order. Onsite water now requires treatment and off-site disposition; and (3) stormwater infiltration has resulted in Strontium-90 levels discharged to the storm drains that exceed NR standards.

The contractor has indicated that water management at SPRU requires major staff resources (at least 50 persons). The purpose of this review is to determine if the contractor's technical approach warrants the large number of staff resources and to ensure that the technical approach is compliant and in accordance with federal, state and NR requirements.

\section{SCOPE}

The selected team of experts will receive hardcopy and electronically, for their information, background materials concerning water management procedures at SPRU, notices of violation, Consent Order and correspondence between DOE and NR on discharges exceeding NR standards that may preclude forward progress of D\&D work at SPRU.

After considering background materials, the team will meet with site personnel at SPRU the week of May 23 to discuss issues or obtain additional information necessary to complete the review.

At the close of the review period, the team will brief DOE SPRU staff on the results of their review. Subsequently, the team will provide a report consisting of a written set of comments. After consideration of comments and preparation of responses, the team will participate in a comment resolution conference call.

The team of experts is expected to apply their expertise in, and prior experience with water management to help DOE identify issues that are affecting or could affect the D\& D work at the SPRU project. In addition, the team is expected to make recommendations on cost-effective technical approaches of the identified issues. 
DOE requests technical assistance from Technical Assistance Team to:

4. Identify critical issues associated with the management and handling of surface/snow melt/run-off water at the SPRU site

5. Identity critical unresolved technical uncertainties associated with the management of surface/snow melt/run-off water at the SPRU site.

6. Evaluate the current and proposed approach for on-site treatment of contaminated surface water at the SPRU site with an emphasis on unit treatment costs and treatment efficacy.

In order to complete this scope, the technical assistance team will:

1. Visit the SPRU site and walk down the components of the surface water management system with a DOE representative who is familiar with the operational history of the surface water management/water treatment system

2. Have a designated technical point of contact that is knowledgeable and can provide access to relevant technical documentation.

\section{TIME AND COST ELEMENTS}

1. Review of background materials

2. On-site visit to discuss issues, tour site and brief DOE on initial comments

3. Preparation of comment report

4. Deliverable-comment report

5. Conference call for comment resolution

6. Follow-on discussion with DOE

\section{ESTIMATED SCHEDULE}

\begin{tabular}{|l|l|l|}
\hline Action/Deliverable & Start Date & Completion Date \\
\hline $\begin{array}{l}\text { Contractor acceptance of } \\
\text { Statement of Work }\end{array}$ & n/a & $5 / 19 / 2011$ \\
\hline Background Material Review & $5 / 19 / 2011$ & $5 / 20 / 2011$ \\
\hline On-site visit & $5 / 23 / 2011$ & $5 / 25 / 2011$ \\
\hline Deliverable-comment report & $5 / 26 / 2011$ & $6 / 2 / 2011$ \\
\hline $\begin{array}{l}\text { Conference Call -comment } \\
\text { resolution }\end{array}$ & $6 / 2 / 2011$ & $6 / 7 / 2011$ \\
\hline Follow-on discussions & $6 / 8 / 2011$ & $6 / 15 / 2011$ \\
\hline
\end{tabular}

